\title{
Banking Across Borders With Heterogeneous Banks
}

Niepmann, Friederike

Please cite paper as:
Niepmann, Friederike (2016). Banking Across Borders With
Heterogeneous Banks.
International Finance Discussion Papers 1177.
http://dx.doi.org/10.17016/IFDP.2016.1177

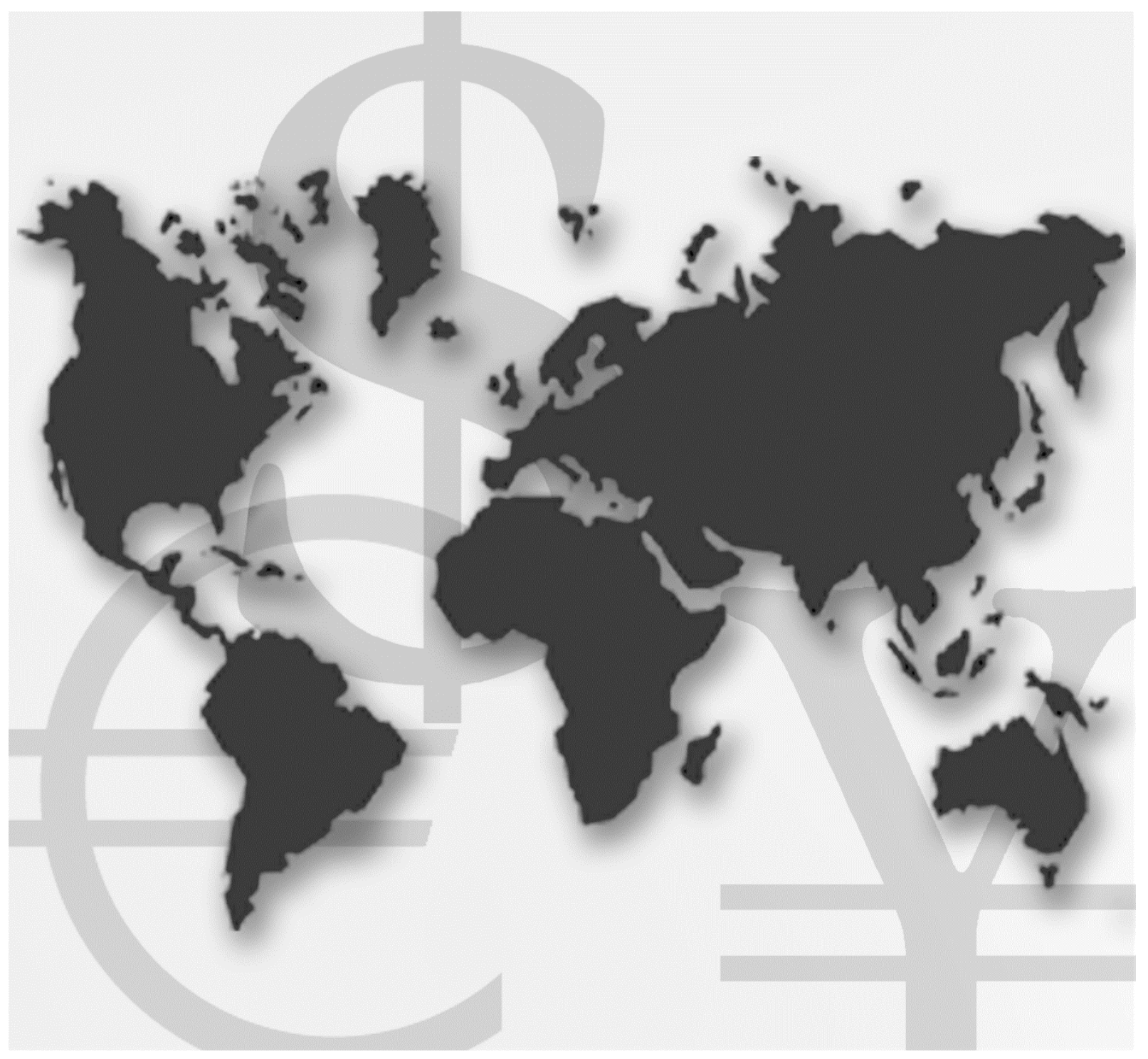

\section{International Finance Discussion Papers}

Board of Governors of the Federal Reserve System

Number 1177

August 2016 
Board of Governors of the Federal Reserve System

International Finance Discussion Papers

Number 1177

August 2016

\section{Banking Across Borders With Heterogeneous Banks}

Friederike Niepmann

NOTE: International Finance Discussion Papers are preliminary materials circulated to stimulate discussion and critical comment. References to International Finance Discussion Papers (other than an acknowledgment that the writer has had access to unpublished material) should be cleared with the author or authors. Recent IFDPs are available on the Web at www.federalreserve.gov/pubs/ifdp/. This paper can be downloaded without charge from the Social Science Research Network electronic library at www.ssrn.com. 


\title{
Banking Across Borders With Heterogeneous Banks*
}

\author{
Friederike Niepmann ${ }^{\dagger}$
}

July 19, 2016

\begin{abstract}
This paper develops a model of banking across borders where banks differ in their efficiencies that can replicate key patterns in the data. More efficient banks are more likely to have assets, liabilities and affiliates abroad and have larger foreign operations. Banks are more likely to be active in countries that have less efficient domestic banks, are bigger and more open to foreign entry. In the model, banking sector integration leads to bank exit and entry and convergence in the return on loans and funding costs across countries. Bank heterogeneity matters for the associated welfare gains. Results suggest that differences in bank efficiencies across countries drive banking across borders, that fixed costs are crucial for foreign bank operations and that globalization makes larger banks even larger.
\end{abstract}

Keywords: cross-border banking, heterogeneity, multinational banks, trade in services JEL-Codes: F12, F21, F23, G21

${ }^{*}$ The author is grateful to Andrew Bernard, Giancarlo Corsetti, and Russell Cooper for advice and encouragement. For their helpful comments, she also thanks Silja Baller, Dean Corbae, Frederic Malherbe, Stefania Garetto, Francesc Ortega, John Romalis, Katheryn Russ, Tim Schmidt-Eisenlohr, Jan-Peter Siedlarek, and participants in seminars at the Federal Reserve Bank of New York, the European University Institute, the University of Oxford, the Inter-American Development Bank, UC Davis, ECB and the FDIC. Special thanks go to Cornelia Kerl, the Research Division and the Research Data and Service Centre of the Deutsche Bundesbank, where part of this paper was written while Niepmann was a visiting researcher. The author also thanks Ina Simonovska for making available some of the data used in this research.

$\dagger$ The author is a staff economist in the Division of International Finance, Board of Governors of the Federal Reserve System, Constitution Avenue NW, Washington, D.C. 20551, USA. Email: Friederike.Niepmann@frb.gov. The views in this paper are solely the responsibility of the author and should not be interpreted as reflecting the views of the Board of Governors of the Federal Reserve System or of any other person associated with the Federal Reserve System. 


\section{Introduction}

Banks today run large foreign operations. At the end of 2014, the foreign assets of banks from 30 BIS reporting countries accounted for 36 percent of their total assets, exceeding $\$ 26$ trillion. ${ }^{1}$ But there is substantial heterogeneity across banks in the geographic coverage and volume of their foreign operations. ${ }^{2}$ As Figure 1 shows, German banks with foreign operations had lower overhead costs to total assets, an inverse measure of efficiency, than the average bank. ${ }^{3}$

This paper presents a general equilibrium model of trade in banking services and financial sector foreign direct investment that sheds light on the drivers of banks' foreign operations, explains the observed heterogeneity and explores the implications of banking sector integration. Using elements from Niepmann (2015) and Holmstrom and Tirole (1997), the model links banks' efficiency and size to their foreign operations in an open economy setup where banking across borders arises from differences in marginal products of capital and banking sector efficiencies across countries. The proposed model is consistent with key empirical regularities in the data, concerning both the extensive and intensive margin of banks' foreign operations.

In the model, banks have two roles. First, they channel capital from depositors to firms. Second, they monitor firms at a cost. Whether banks monitor is not observable by depositors so to credibly commit to monitor, banks invest their own capital in the firms they lend to. Banks with lower monitoring costs are able to intermediate more external capital for the same amount of equity capital and make higher profits. ${ }^{4}$

This microstructure carries over to the open economy where countries can differ in their relative endowments of capital and labor, production technologies and banking sector efficiencies. These differences cause the return on loans that banks earn and the rate on deposits they pay to vary across countries. When banking sectors integrate, banks lend and borrow

\footnotetext{
${ }^{1}$ These numbers are based on data from the Consolidated Banking Statistics provided by the BIS on an ultimate risk basis. See http://stats.bis.org/statx/srs/table/b1?p=20144\&c=.

${ }^{2}$ Equivalent relationships have been documented in depth for manufacturing firms. See Bernard et al. (2012) for a recent survey of empirical works on firm heterogeneity and international trade.

${ }^{3}$ For details on the underlying data, see section 5.

${ }^{4}$ In the model, bank capital is fixed and cannot relocate from one bank to the other preventing the most efficient bank from serving the entire market.
} 
across borders to maximize the return on loans and to minimize funding costs.

Banks have the choice between two different modes to serve foreign markets. They can either lend and borrow cross-border, or they can establish an affiliate abroad (invest in FDI). It is assumed that the fixed costs of cross-border lending and borrowing are lower than the fixed cost of FDI and that banks save on variable costs by opening up a foreign affiliate. As more efficient banks have larger lending volumes and make higher profits, only they are able to cover the higher fixed costs. Therefore sorting occurs: the most efficient banks establish foreign affiliates abroad, while less efficient banks engage only in cross-border lending and borrowing. Banks at the lower end of the efficiency distribution remain domestic. ${ }^{5}$

When the two banking sectors become integrated and banks borrow and lend across borders, intermediation costs and returns to capital converge. Capital relocates from the capital abundant/low technology country to the capital scarce/high technology country. In the country that hosts the more efficient banking sector, new banks enter. In the other country, the least efficient banks exit as foreign banks intermediate local deposits. Because banks that go global can increase their return on loans and lower their funding costs, their balance sheets expand. Through these mechanisms, banking across borders affects the equilibrium bank size distribution, which tends to become more unequal. A simulation of the model shows that the welfare gains from banking sector integration depend on the degree of bank heterogeneity in the liberalizing countries, illustrating the relevance of taking efficiency and size differences across banks into account. ${ }^{6}$

The empirical analysis draws on information on the external positions of banks and bank balance sheets for 2005 available at the Deutsche Bundesbank. ${ }^{7}$ They contain detailed information on the foreign activities of all German banks and their affiliates in a large number of countries. As a proxy for the efficiency of single banks, I use two simple accounting measures: a bank's overhead costs as a ratio to total assets and labor productivity. 99

\footnotetext{
${ }^{5}$ This is similar to Melitz (2003) and Helpman et al. (2004) where manufacturing firms sort into FDI and exporting according to their productivity levels.

${ }^{6}$ In contrast to this paper, the model in Niepmann (2015) with perfectly competitive, homogenous banks, predicts equal welfare gains when average intermediation costs in the integrating countries are the same.

${ }^{7}$ Research Data and Service Centre of the Deutsche Bundesbank, External Position of Banks (AUSTA - "Auslandsstatus der Banken"), Monthly Balance Sheet Statistics (BISTA - "Monatliche Bilanzstatistik"), Income and Loss Data (GuV - "Gewinn und Verlustrechnung der Banken"), 2005.
} 
percent of German banks have assets in foreign countries. However, most banks have assets and liabilities in only a handful of countries, while the top German banks cover more than 150 countries. Operating affiliates abroad is much less common. Only 2.6 percent of German banks have affiliates and these affiliates span only 58 different countries.

Beyond establishing these facts, the derived dataset is used to support key predictions of the model. A first set of regressions explores the role of bank efficiency for balance sheet sizes and foreign operations. First, banks with lower overhead cost are larger and more levered. Second, as indicated in figure 1, banks with lower overhead costs are more likely to have cross-border assets, cross-border liabilities and affiliates in foreign countries. Third, conditional on operating abroad, the volume of their foreign activities is larger.

The model also predicts how the operations of banks vary with foreign country characteristics. Specifically, the number of firms that are active abroad should increase with the size of a country and decrease with the efficiency of its banking sector as well as the fixed and variable costs of operating there. Logit regressions, where the dependent variable takes a value of 1 if a bank $k$ has foreign assets, liabilities or affiliates in country $i$ confirm that German banks are more likely to operate in countries with a larger GDP, a less efficient banking sector, higher bureaucratic quality and financial freedom and a smaller geographic distance. The sorting of banks into foreign markets based on their efficiency and host country characteristics is so strong that these factors explain the vast portion of the variation in the average efficiency and the minimum efficiency of German banks that operate in various foreign countries.

The presented results have several implications. The fact that the average efficiency of banks that operate in country $i$ increases with the efficiency of the banking sector in country $i$ strongly suggests that differences in intermediation costs across countries are a key driver of banking across borders. Second, the stark sorting pattern indicates that foreign bank activities are associated with substantial fixed costs, which only banks with larger operating volumes are able to overcome. Third, banking across borders allows banks to grow their balance sheets. Since only the largest banks are active abroad, banking sector integration tends to make large banks even larger. Finally, bank heterogeneity matters since it influences how banking sector integration affects net interest rate margins, capital flows and welfare. 
Related Literature This research contributes to the small but growing literature on crossborder banking. Similar to Niepmann (2015), this paper takes a trade approach where differences in relative factor endowments and financial intermediation technologies across countries drive banking across borders. In contrast to the aforementioned work, the framework presented here exhibits imperfect competition and allows for bank-level heterogeneity.

A few other papers also study the effects of increased competition and banking sector integration in the presence of heterogeneous banks. Ennis (2001) incorporates a moral hazard problem at the side of bankers in a multi-regional banking model, focussing on the effect of integration on the size distribution of banks. In his model, banks differ with respect to equity, in contrast to the efficiency differences modeled here. Banking across regions allows the bank with the largest equity to diversify lending, which relaxes information problems and increases profits.

De Blas and Russ $(2010,2012)$ study the effects of financial liberalization on banks' loan pricing and the distribution of markups. ${ }^{8}$ The former paper relies on a structure where banks offer differentiated services in line with Bernard et al. (2003). In the latter work, banks with different efficiencies coexist, as not all firms can visit the most efficient bank. Cross-border lending arises because firms apply for loans also at foreign banks to minimize expected costs. FDI and cross-border lending are analyzed as separate scenarios.

Corbae and D'Erasmo (2010) propose a DSGE model to study the effect of bank competition on bank market structure, entry and exit and the riskiness of bank loans along the business cycle, distinguishing between regional and global banks. In an application of that model, Corbae and D'Erasmo (forthcoming) evaluate the welfare effects of foreign bank entry in Mexico. Recently, Fillat et al. (2015) provide a structural model with bank heterogeneity, analyzing how banks' mode of entry (through either branches or subsidiaries) affects the transmission of foreign shocks to the United States. Kerl and Niepmann (forthcoming) simplify the model in this paper to explain the sectoral composition of international bank flows, distinguishing between interbank market activity and cross-border business with non-banking firms and households.

More broadly this research adds to the literature on heterogeneous firms in international

\footnotetext{
${ }^{8}$ De Blas and Russ (2010) is an earlier version of De Blas and Russ (2012).
} 
trade and investment. The proposed theoretical structure differs substantially from existing work-horse models with firm heterogeneity. In the class of models following Melitz (2003), heterogeneous manufacturing firms produce differentiated goods as a result of consumers' love for variety and labor, the only production factor is immobile. In this paper instead, banks provide a homogenous intermediation service and move capital across borders. In this regard, this work also contributes to services trade research (see Francois and Hoekman (2010) for a literature review).

The assumptions on fixed and variables costs that banks face follow Helpman et al. (2004) and result in a similar concentration-fixed-cost tradeoff here. Buch et al. (2014) and Lehner (2009) model such a tradeoff for banks in partial equilibrium frameworks in contrast to the general equilibrium approach in this paper.

This work also extends the empirical literature on cross-border banking. Several papers have analyzed how country characteristics affect the foreign activities of banks (see, for example, Papaioannou (2009); Buch (2003); Buch (2005); Focarelli and Pozzolo (2005)). Niepmann (2015) shows that the foreign positions of banks are determined by differences in relative factor endowments and banking sector efficiencies between countries. Buch et al. (2011) introduce the dataset explored in this paper, documenting that the foreign operations of German banks vary systematically with their size and productivity. ${ }^{9}$ The empirical analysis in this paper complements these works, in particular by analyzing the sorting of banks into foreign activities based on host country characteristics.

The paper is structured as follows. Section 2 presents the closed economy model. Section 3 discusses the open economy setup. Section 4 solves the model analytically and simulates it for the case where relative factor endowments and production technologies are the same across countries. Section 5 explores patterns in the German bank-level data. Section 6 concludes.

\footnotetext{
${ }^{9}$ For follow-up version of that paper, see Buch et al. (2014).
} 


\section{The Closed Economy Model}

\subsection{Setup}

There is a continuum of capitalists of measure $K$, who can become bankers or depositors, and a continuum of workers of measure $L$. Each capitalist is endowed with one unit of capital. Each worker supplies inelastically one unit of labor. Furthermore, there is a continuum of potential entrepreneurs who can run firms. Firms are perfectly competitive and produce a single consumption good using capital and labor. Each firm operates under the same constant returns to scale technology. The production function takes the form $F(A, l, z)$. $A$ is a productivity parameter and $F(A, l, z)$ is assumed to be a continuous function, strictly increasing and concave in $l$. The capital input per firm $z$ is fixed. ${ }^{10}$

There are two periods: in the first period, investments are made. In the second period, firms produce. With probability $\lambda$, production is successful so that capitalists and workers are paid and consume. It is useful to determine equilibrium factor prices first. In equilibrium, all capital is employed in production, which implies that the measure of operating firms is $N=K / z{ }^{11}$ As firms compete for labor and are symmetric, they employ the same amount of labor $l$. Labor market clearing implies that $l=L / N$. Under perfect competition, the returns to the production factors are pinned down by their marginal products. The gross return to capital is $R=\left(1+F_{z}(1, z / l)\right)=\left(1+F_{K}(1, K / L)\right)$. The wage rate is given by $w=F_{L}(1, K / L)$.

Each capitalist decides whether to become a banker or a depositor in the first period. Bankers have two tasks in the economy: first, they channel capital from depositors to firms. Second, they monitor the firms they lend to at a cost to increase the probability that production is successful. As the suppliers of capital, bankers collect the gross return to capital $R$ in the second period. Depositors invest their endowments in banks and obtain the return $R^{D}$, which is endogenously determined. Before each capitalist makes his occupational choice, he learns about his efficiency as a banker. Each capitalist draws a monitoring cost $\gamma>0$ from

\footnotetext{
${ }^{10}$ Instead of fixing $z$ exogenously, one could endogenously limit the size of a single firm by formulating the moral hazard problem at the side of the entrepreneur similar to Ju and Wei (2010).

${ }^{11}$ Capitalists do not have available a storage technology.
} 
a continuous distribution $g(\gamma)$ with support $\gamma \in[\underline{\gamma}, \bar{\gamma}]$. The lower the cost draw the higher the capitalist's efficiency as a banker.

The role of monitoring and incentive problems in the model is similar to the framework in Holmstrom and Tirole (1997) with double-sided moral hazard. First, the success probability of the firm depends on the effort exerted by the entrepreneur. With effort, the success probability is $\lambda$. Without effort, it is $\lambda_{L}<\lambda$. Only monitoring by banks induces the entrepreneur to exert effort.

Second, bankers only monitor if they have an incentive to do so. ${ }^{12}$ To credibly commit to monitor, a banker invests his own capital in the firms he lends to. ${ }^{13}$ Incentive compatibility requires that the banker's expected return under monitoring is higher than the return without monitoring, which results in the following condition:

$$
\lambda R z-\lambda R^{D}(z-v)-\gamma z \geq \lambda_{L} R z-\lambda_{L} R^{D}(z-v),
$$

where $\gamma z$ are the total monitoring costs incurred and $v$ represents the banker's capital (equity) invested in the firm. To maximize profits, each banker maximizes the number of firms he monitors and lends to. This implies minimizing $v \cdot{ }^{14}$ Therefore, in equilibrium, condition 1 holds with equality. Solving the condition for bank capital $v(\gamma)$ yields:

$$
v(\gamma)=\left(1-\frac{R}{R^{D}}+\frac{\gamma}{\left(\lambda-\lambda_{L}\right) R^{D}}\right) z
$$

The model puts some discipline on the magnitude of monitoring costs. Monitoring costs are assumed to be sufficiently low so that all firms are monitored by banks and operate with a high probability of success in equilibrium. At the same time, monitoring costs have to be sufficiently high so that the incentive compatibility constraint of even the most efficient

\footnotetext{
${ }^{12}$ Depositors do not observe whether bankers monitor but can observe a banker's monitoring cost (type) $\gamma$.

${ }^{13}$ It is assumed that the success of firms is perfectly correlated so that banks must invest their own capital to solve the moral hazard problems. See Holmstrom and Tirole (1997).

${ }^{14}$ To see this, substitute $n=1 / v$ in the expression for total profits to obtain $\pi=n\left(\lambda R z-\lambda R^{D} z-\gamma z\right)+\lambda R$.
} 
banker $\underline{\gamma}$ binds in equilibrium. ${ }^{15}$

As bank capital $v(\gamma)$ invested per firm is proportional to the capital input $z$ of the firm, $z$ is normalized to 1 . The return of a banker with monitoring cost $\gamma$ per firm that he monitors and lends to is then obtained as:

$$
\lambda R-\lambda R^{D}(1-v(\gamma))-\gamma=\frac{\gamma \lambda_{L}}{\lambda-\lambda_{L}}
$$

The number (measure) of firms that one banker endowed with one unit of capital can monitor is $n(\gamma)=\frac{1}{v(\gamma)} \cdot{ }^{16}$ The higher a banker's monitoring efficiency, that is, the lower $\gamma$, the more external capital he channels from depositors to firms and the larger his balance sheet becomes. ${ }^{17}$ A banker of type $\gamma$ operates under the following leverage:

$$
\frac{\text { debt }}{\text { equity }}=\frac{\text { depositor capital }}{\text { bank capital }}=\frac{n(\gamma) x(\gamma)}{1}=\frac{1}{v(\gamma)}-1 \text {, }
$$

where $x(\gamma)=1-v(\gamma)$ is the depositor capital that a banker of type $\gamma$ lends to a single firm. Profits of the banker of type $\gamma$ are given by:

$$
\begin{aligned}
\pi(\gamma) & =n(\gamma)\left(\lambda R-\lambda R^{D}(1-v(\gamma))-\gamma\right)=\frac{1}{v(\gamma)} \frac{\gamma \lambda_{L}}{\lambda-\lambda_{L}} \\
& =\frac{1}{1-\frac{R}{R^{D}}+\frac{\gamma}{\left(\lambda-\lambda_{L}\right) R^{D}}} \frac{\gamma \lambda_{L}}{\lambda-\lambda_{L}} .
\end{aligned}
$$

The return that the banker makes per firm, which corresponds to the second term in expression (6), depends only on the banker's monitoring cost $\gamma$ and on the success probabilities $\lambda$ and $\lambda_{L}$. These parameters are exogenous and fixed. The lower $\gamma$, the higher $\lambda$ and the

\footnotetext{
${ }^{15}$ Sufficient conditions are:

$$
\int_{\underline{\gamma}}^{\gamma=R\left(\lambda-\lambda_{L}\right)}\left(\frac{1}{1-\frac{\lambda}{\lambda_{L}}+\frac{\gamma \lambda}{\left(\lambda-\lambda_{L}\right) \lambda_{L} R}}-1\right) g(\gamma) d \gamma>\int_{\gamma=R\left(\lambda-\lambda_{L}\right)}^{\bar{\gamma}} g(\gamma) d \gamma .
$$

and $\underline{\gamma}>\left(\lambda-\lambda_{L}\right) R\left(1-\frac{\lambda_{L}}{\lambda}\right)$. The first condition requires that at the deposit rate $R^{D}=\lambda_{L} / \lambda R$, the demand for external funds by bankers is larger than the supply of funds by depositors to bankers. This ensures that in equilibrium $R^{D}>\lambda_{L} / \lambda R$ and $\gamma^{*}<R\left(\lambda-\lambda_{L}\right)$. The second condition requires that at the deposit rate $R^{D}=\lambda_{L} / \lambda R$, the incentive compatibility constraint is binding for the most efficient banker. From these conditions, it follows that in equilibrium, $\lambda R-\gamma \geq \lambda R^{D} \forall \gamma \leq \gamma^{*}$ and $\lambda R^{D}>\lambda_{L} R$.

${ }^{16}$ Integer problems are ignored. One firm may borrow from several banks.

${ }^{17}$ The relationship between efficiency, bank size and leverage in the model is consistent with the data as shown in section 5.3. See also Kalemli-Ozcan et al. (2012) who find that larger banks have a higher leverage.
} 
lower $\lambda_{L}$ are, the higher are the banker's profits. The endogenous variables of the model, $R$ and $R^{D}$, affect profits only through the measure of firms $n(\gamma)$ that the banker serves, i.e. through the lending volume, and, as bank capital is fixed, through leverage. The banker's lending volume and profits increase with the gross return to capital $R .^{18}$ Profits decrease with the the cost of external funding $R^{D} .19$

While the profits of a banker depend on his type $\gamma$, all depositors are paid the same return. This is because the monitoring cost draw of a depositor is assumed to remain private information in contrast to the draw of a banker.

\subsection{Equilibrium}

Two equilibrium conditions close the model. First, there is free entry into banking. Second, the market for financial intermediation clears, i.e. all operating bankers in the economy intermediate capital $K$.

First, consider free entry into banking. Each capitalist has the choice between becoming a banker or a depositor. The marginal capitalist $\gamma^{*}$ who is indifferent between the two occupational choices is determined by setting the expected profits of a capitalist as a banker equal to his expected profits as a depositor:

$$
\pi\left(\gamma^{*}\right)=\frac{1}{1-\frac{R}{R^{D}}+\frac{\gamma^{*}}{\left(\lambda-\lambda_{L}\right) R^{D}}} \frac{\gamma^{*} \lambda_{L}}{\lambda-\lambda_{L}}=\lambda R^{D}
$$

Because profits are strictly decreasing in $\gamma$, all capitalists for whom $\gamma>\gamma^{*}$ become depositors and those for whom $\gamma \leq \gamma^{*}$ become bankers.

All active bankers together must intermediate the existing capital in the economy. The economy is endowed with capital of measure $K$. A banker of type $\gamma$ is able to supply a measure of $n(\gamma)$ firms with capital. Thus the market for financial intermediation clears if:

$$
K \int_{\underline{\gamma}}^{\gamma^{*}} n(\gamma) g(\gamma) d \gamma=K
$$

\footnotetext{
${ }^{18} \mathrm{~A}$ shock to productivity $A$ increases $R$. Thus, lending, leverage and profits are procyclical in line with the empirical evidence. See e.g. Adrian and Shin (2014).

${ }^{19}$ Because $\lambda R-\lambda_{L} R-\gamma>0 \forall \gamma<\gamma^{*}$, the derivative of $\pi(\gamma)$ with respect to $R^{D}$ is always negative.
} 
Equations (7) and (8) constitute a system of two equations in two unknowns $R^{D}$ and $\gamma^{*}$, which fully determine the equilibrium. Solving equation (7) with respect to $R^{D}$ yields:

$$
R^{D}=R-\frac{\gamma^{*}}{\lambda}=\left(1+F_{K}\left(1, \frac{K}{L}\right)\right)-\frac{\gamma^{*}}{\lambda}
$$

The return to depositors $R^{D}$ depends on the marginal product of capital (MPK) and, therefore, on the relative factor endowments of the economy, as well as on banking sector efficiency reflected in $\gamma^{*}$. The lower banking sector efficiency in the economy, the larger the wedge between the gross return to capital $R$ and the return on deposits $R^{D}$ becomes. ${ }^{20}$

Plugging the expression for $R^{D}$ into the market clearing condition (8) delivers:

$$
1=\int_{\underline{\gamma}}^{\gamma^{*}} \frac{\left(R-\frac{\gamma^{*}}{\lambda}\right)\left(\lambda-\lambda_{L}\right)}{\gamma-\left(\lambda-\lambda_{L}\right) \frac{\gamma^{*}}{\lambda}} g(\gamma) d \gamma
$$

Expression (10) implicitly gives a solution for the bank entry cutoff $\gamma^{*}$.

Proposition 1 The solution $\gamma^{*}$ to

$$
1=\int_{\underline{\gamma}}^{\gamma^{*}} \frac{\left(R-\frac{\gamma^{*}}{\lambda}\right)\left(\lambda-\lambda_{L}\right)}{\gamma-\left(\lambda-\lambda_{L}\right) \frac{\gamma^{*}}{\lambda}} g(\gamma) d \gamma
$$

is unique and exists under the sufficient conditions:

$$
\int_{\underline{\gamma}}^{\gamma=R\left(\lambda-\lambda_{L}\right)} \frac{1}{1-\frac{\lambda}{\lambda_{L}}+\frac{\gamma \lambda}{\left(\lambda-\lambda_{L}\right) \lambda_{L} R}} g(\gamma) d \gamma>1
$$

and

$$
\underline{\gamma}>\left(\lambda-\lambda_{L}\right) R\left(1-\frac{\lambda_{L}}{\lambda}\right)
$$

Proof. See appendix A.

The equilibrium cutoff $\gamma^{*}$ is a function of the parameters of the model. The lower the gross return to capital $R$ is, the smaller is the amount of external capital a single banker can

\footnotetext{
${ }^{20}$ This is similar to Antras and Caballero (2009) and Ju and Wei (2010).
} 
intermediate. As a consequence, the bank entry cutoff increases with the capital-labor ratio $K / L$ and decreases with productivity $A$. In addition, the bank entry cutoff is affected by changes in the monitoring cost distribution. The more efficient the banking sector is overall, the fewer banks are needed to intermediate the available capital in the economy and the lower is $\gamma^{*}$.

\section{The Open Economy Model}

\subsection{Setup}

In the open economy, there are two countries home $(\mathrm{h})$ and foreign $(\mathrm{f})$, which can differ in their relative endowments of capital and labor, in the productivity of domestic firms and in aggregate banking sector efficiency so that autarky returns to capital $R$ and deposit rates $R^{D}$ may vary across countries.

Workers, entrepreneurs and depositors are assumed to be immobile. ${ }^{21}$ In contrast, banks can operate in both countries. They have the choice between raising deposits at home and abroad and between investing at home and abroad. Operating internationally is costly, however. If a banker in country $j \in\{h, f\}$ wants to extend loans to firms in country $i \in\{h, f\}$ where $i \neq j$, he has to incur the fixed cost $f_{i j}^{L}>0$. If he wants to borrow from foreign depositors, he has to pay the fixed cost $f_{i j}^{B}>f_{i j}^{L}$. Once $f_{i j}^{B}$ is incurred, the banker does not have to pay an extra cost to extend cross-border loans. ${ }^{22}$ In addition to fixed costs, the banker also faces variable costs, which take the form of "iceberg" costs. If the gross return $R_{i}$ is collected in country $i$, only a fraction of the return, $\tau R_{i}$, where $\tau<1$, arrives at the bank in country $j$. At the same time, for the return $R_{i}^{D}$ to go to depositors in country $i, \phi R_{i}^{D}$ units have to be transported, where $\phi>1 .{ }^{23}$ Banks can eliminate variable costs by

\footnotetext{
${ }^{21}$ In reality, a share of financial investors is mobile. However, some investor capital may become mobile only through banks. This should in particular be true for deposits, which represent an important funding source for banks.

${ }^{22}$ Alternative fixed cost structures could be modeled. This structure implicitly assumes that there are synergies between borrowing and lending.

${ }^{23}$ In models of goods trade, iceberg costs reflect variable trade costs that increase in the distance between the importing and the exporting country. Degryse and Ongena (2005) find that distance-related transportation costs matter also in banking, in support of the modeling choice here. See Brevoort and Wolken (2009) for a summary of the literature on the role of distance in banking.
} 
opening up an affiliate abroad. However, establishing a foreign affiliate (making a foreign direct investment, FDI) requires paying a higher fixed cost $f_{i j}^{A}>f_{i j}^{B}$.

The profits of a banker in country $j$ who raises deposits at home and invests them in country $i$ through cross-border lending are given by:

$$
\pi_{i j}^{X}\left(\gamma_{j}\right)=n\left(\gamma_{j}, \tau R_{i}, R_{j}^{D}\right) \frac{\gamma_{j} \lambda_{L}}{\lambda-\lambda_{L}}-f_{i j}^{L}=\frac{1}{1+\frac{1}{R_{j}^{D}}\left(\frac{\gamma}{\lambda-\lambda_{L}}-\tau R_{i}\right)} \frac{\gamma_{j} \lambda_{L}}{\lambda-\lambda_{L}}-f_{i j}^{L}
$$

The first subscript in $\pi_{i j}^{X}$ stands for the country to which the banker lends. The second subscript indicates where capital is raised. Superscript $X$ indicates that the banker operates cross-border rather than through an affiliate which is denoted by superscript $A . n\left(\gamma_{j}, R_{i}, R_{j}^{D}\right)$ reflects the total capital that the banker of type $\gamma_{j}$ intermediates, which depends on his monitoring cost $\gamma_{j}$, the gross return to capital he collects and the deposit rate he has to pay.

Accordingly, a banker that raises deposits abroad to finance lending at home collects:

$$
\pi_{j i}^{X}\left(\gamma_{j}\right)=n\left(\gamma_{j}, R_{j}, \phi R_{i}^{D}\right) \frac{\gamma_{j} \lambda_{L}}{\lambda-\lambda_{L}}-f_{i j}^{B}=\frac{1}{1+\frac{1}{\phi R_{i}^{D}}\left(\frac{\gamma}{\lambda-\lambda_{L}}-R_{j}\right)} \frac{\gamma_{j} \lambda_{L}}{\lambda-\lambda_{L}}-f_{i j}^{B}
$$

If instead the banker borrows from depositors abroad and lends to firms abroad (local intermediation), his profits are:

$$
\pi_{i i}^{X}\left(\gamma_{j}\right)=\frac{1}{1+\frac{1}{\phi R_{i}^{D}}\left(\frac{\gamma}{\lambda-\lambda_{L}}-\tau R_{i}\right)} \frac{\gamma_{j} \lambda_{L}}{\lambda-\lambda_{L}}-f_{i j}^{B}
$$

Finally, the entrepreneur can invest in FDI. In this case, $\tau$ and $\phi$ are equal to one, and the fixed cost is replaced by $f_{i j}^{A}$ in the last three equations.

Each banker chooses between the seven options $\left(\pi_{j j}, \pi_{i j}^{X}, \pi_{i i}^{X}, \pi_{j i}^{X}, \pi_{i j}^{A}, \pi_{i i}^{A}\right.$, and $\left.\pi_{j i}^{A}\right)$ taking the gross returns to capital $R_{i}$ and $R_{j}$, the returns on deposits $R_{i}^{D}$ and $R_{j}^{D}$ as well as costs as given. 


\section{$3.2 \quad$ Sorting}

It is useful to establish a key result of the model before defining the equilibrium in the open economy: bankers sort into cross-border lending, borrowing and FDI according to their monitoring cost $\gamma$.

Consider the general profit function:

$$
\pi\left(R, R^{D}, \gamma, \tau, \phi\right)=\frac{1}{1-\frac{\tau R}{\phi R^{D}}+\frac{\gamma}{\left(\lambda-\lambda_{L}\right) \phi R^{D}}} \frac{\gamma \lambda_{L}}{\lambda-\lambda_{L}} .
$$

Substitute $\tilde{R}^{D}=\phi R^{D}$ and $\tilde{R}=\tau R$. The function $\pi\left(\tilde{R}, \tilde{R}^{D}, \gamma\right)$ is supermodular in $\gamma$ and $-\tilde{R}$ and in $\gamma$ and $\tilde{R}^{D}$, i.e. $\pi_{-\tilde{R}, \gamma}>0$ and $\pi_{\tilde{R}^{D}, \gamma}>0$. Mrazova and Neary (2011) show that supermodularity is a sufficient condition for sorting in a way that the high-efficiency banks engage in the activity that requires paying the (higher) fixed cost, whereas low-efficiency banks engage in the activity with no (the lower) fixed cost. This result facilitates the equilibrium computation because once the banker who is indifferent between two activities is found, the decisions of all other active bankers follow immediately.

Proposition 2 If bankers of different types engage in different activities in equilibrium, then sorting is such that the most efficient bankers sort into the activity that requires paying the (higher) fixed cost while the low efficiency bankers engage in the activity with no (the lower) fixed cost.

Proof. See appendix A.

In the following, $\gamma_{j}^{L}\left(\gamma_{j}^{B}\right)$ denotes the cross-border lending (borrowing) cutoff, that is, all bankers with $\gamma_{j} \leq \gamma_{j}^{L}\left(\gamma_{j}^{B}\right)$ find it profitable to lend (borrow) across borders. Similarly, all bankers with $\gamma_{j} \leq \gamma_{j}^{A}$ find it profitable to operate in country $i$ by establishing an affiliate there. A banker is only willing to pay a fixed cost if he can collect a higher return on the loan or obtain cheaper funding abroad. Once the cost is incurred, it is optimal for the banker to invest all capital in the high return location and to raise all deposits in the low-interest country. Similarly, if a bank opens up a foreign representation, it conducts all business through the foreign affiliate to save on variable costs. ${ }^{24}$

\footnotetext{
${ }^{24}$ Bankers will always choose to raise deposits either at home or abroad. They will also, in general, either
} 
Because more efficient banks are larger, that is, they borrow and lend more, they also hold more cross-border assets, cross-border liabilities as well as more assets and liabilities in their foreign affiliates. The model therefore predicts not only that the extensive margins of banking across borders co-vary positively with bank efficiency but also the different intensive margins.

Corollary 1 Bankers with lower monitoring costs are more likely to lend and borrow abroad and to have foreign affiliates. Conditional on operating abroad, their foreign operations have higher volumes.

\subsection{Equilibrium definition}

The equilibrium in the open economy is defined as follows:

Definition 1 An equilibrium in the open economy is characterized by the bank entry cutoff $\gamma_{j}^{*}$, the cross-border lending cutoff $\gamma_{j}^{L}$, the cross-border borrowing cutoff $\gamma_{j}^{B}$, the FDI cutoff $\gamma_{j}^{A}$, returns to depositors $R_{j}^{D}$ and gross returns to capital $R_{j}$ for $j \in\{h, f\}, i \in\{h, f\}$ and $j \neq i$ for which the following conditions hold:

(i) Capitalists in each country optimally choose whether to become depositors or bankers.

(ii) Bankers in each country optimally choose to lend at home and abroad.

(iii) Bankers in each country optimally choose to raise capital at home and abroad.

(iv) Bankers in each country optimally choose between the two modes of operating abroad (cross-border versus FDI).

(v) Capital flows are consistent with the choice of bankers to invest and to raise capital abroad.

(vi) Labor markets clear.

(vii) All capital is employed in production (capital market clearing).

(viii) The market for financial intermediation clears.

invest at home or abroad. These results could be relaxed by introducing heterogeneous firms/depositors leading to assortative matching or by including a motive for banks and depositors to diversify lending and borrowing. 


\section{Analytical Solution with $\frac{K_{h}}{L_{h}}=\frac{K_{f}}{L_{f}}, A_{h}=A_{f}, \tau=1$}

In the following, it is assumed that the two countries operate the same production technology and have the same relative factor endowments, that is, $\frac{K_{h}}{L_{h}}=\frac{K_{f}}{L_{f}}$ and $A_{h}=A_{f}$, but that they differ in their banking sector efficiencies. As a result, autarky returns to capital are the same while autarky deposit rates vary across the two countries. To make the model even more tractable, $\tau$ is set equal to 1 , that is, there are no variable costs associated with lending across borders.

When technologies and returns to capital are the same in both countries, the allocation of capital is efficient and, because of $\tau=1$, unaffected by banks' foreign operations. Because cross-border lending is costless once the fixed cost $f^{B}$ or $f^{A}$ have been incurred, banks will always lend across borders so that gross returns remain equalized. As a result, the net capital flow is zero in equilibrium and $R$ can be taken as given and fixed.

Without loss of generality, the home country is assumed to host the more efficient banking sector so that the autarky deposit rate is lower in the foreign than in the home country. This gives home banks an incentive to raise funding in the foreign country. Monitoring costs are

assumed to be Pareto distributed with the same shape parameter $a, \gamma_{h} \in\left[\underline{\gamma}_{h}=\underline{\gamma}, \infty\right]$ and $\gamma_{f} \in\left[\underline{\gamma}_{f}=\underline{\gamma}+\Delta, \infty\right]$.

The notation can be simplified and subscripts dropped. The profits of a home banker who raises deposits in the foreign country, borrowing cross-border without an affiliate, are given by:

$$
\pi^{X}\left(\gamma_{h}\right)=n\left(\gamma_{h}, R, \phi R_{f}^{D}\right) \frac{\gamma_{h} \lambda_{L}}{\lambda-\lambda_{L}}-f^{B}=\frac{1}{1+\frac{1}{\phi R_{f}^{D}}\left(\frac{\gamma_{h}}{\lambda-\lambda_{L}}-R\right)} \frac{\gamma_{h} \lambda_{L}}{\lambda-\lambda_{L}}-f^{B}
$$

Accordingly, the profits of a banker from the home country that raises deposits abroad through a local affiliate are:

$$
\pi^{A}\left(\gamma_{h}\right)=n\left(\gamma_{h}, R, R_{f}^{D}\right) \frac{\gamma_{h} \lambda_{L}}{\lambda-\lambda_{L}}-f^{A}=\frac{1}{1+\frac{1}{R_{f}^{D}}\left(\frac{\gamma_{h}}{\lambda-\lambda_{L}}-R\right)} \frac{\gamma_{h} \lambda_{L}}{\lambda-\lambda_{L}}-f^{A}
$$




\subsection{Equilibrium}

I focus on the interesting case of an interior solution. For this, $\Delta$ cannot be be too big. Moreover, size differences cannot be too large so that some capitalists in the foreign country operate as bankers in the open economy equilibrium and not all capitalists in the home country become bankers. To exclude autarky as the equilibrium, variable and fixed costs cannot be prohibitively high. Due to the complexity of the model, it is not possible to characterize the exact parameter space for which an interior solution results although it is easy to come up with examples. If there is an interior solution, it is unique.

The result on sorting derived in the previous section implies that home bankers will sort, in such an equilibrium, into cross-border borrowing and FDI according to their monitoring costs. Define $\gamma_{h}^{B}$ as the solution to $\pi^{X}\left(\gamma_{h}, \phi R_{f}^{D}, R\right)=\pi\left(\gamma_{h}, R_{h}^{D}, R\right)$ and $\gamma_{f}^{F}$ as the solution to $\pi^{F}\left(\gamma_{h}, R_{f}^{D}, R\right)=\max \left\{\pi\left(\gamma_{h}, R_{h}^{D}, R\right), \pi^{X}\left(\gamma_{h}, \phi R_{f}^{D}, R\right)\right\} .^{25}$ Then three cases are possible: in equilibrium, (i) $\underline{\gamma}_{h}<\gamma_{h}^{F}<\gamma_{h}^{B}$, (ii) $\gamma_{h}^{F} \leq \underline{\gamma}_{h}<\gamma_{h}^{B}$, or (iii) $\underline{\gamma}_{h}<\gamma_{h}^{F}$ and $\gamma_{h}^{B} \leq \gamma_{h}^{F}$. In case (i), some home bankers borrow cross-border from depositors abroad, while other bankers use affiliates for it. In case (ii), the fixed cost of FDI $f^{A}$ is too high for banks to establish foreign affiliates in equilibrium. In case (iii), the fixed cost of $\operatorname{FDI} f^{A}$ is relatively low so that all banks that borrow from abroad establish foreign affiliates.

Let $E$ denote the total equity of banks in the home country that borrow from abroad and let $D$ denote the deposits that these banks raise in the foreign country. Then an interior solution is characterized by the following equations:

$$
\begin{aligned}
K_{f}-D & =K_{f} \int_{\underline{\gamma_{f}}}^{\gamma_{f}^{*}} n\left(\gamma_{f}, R, R_{f}^{D}\right) g_{f}\left(\gamma_{f}\right) d \gamma_{f}, \\
K_{h} & =E+K_{h} \int_{\max \left\{\gamma_{h}^{A}, \gamma_{h}^{B}\right\}}^{\gamma_{h}^{*}} n\left(\gamma_{h}, R, R_{h}^{D}\right) g_{h}\left(\gamma_{h}\right) d \gamma_{h} \\
\pi\left(\gamma_{f}^{*}\right) & =\lambda R_{f}^{D}, \\
\pi\left(\gamma_{h}^{*}\right) & =\lambda R_{h}^{D}, \\
\pi^{X}\left(\gamma_{h}^{B}\right) & =\pi\left(\gamma_{h}^{B}\right), \\
\pi^{A}\left(\gamma_{h}^{A}\right) & =\max \left\{\pi\left(\gamma_{h}^{A}\right), \pi^{X}\left(\gamma_{h}^{A}\right)\right\},
\end{aligned}
$$

\footnotetext{
${ }^{25}$ Note that each profit function cuts the other ones at most once for permissible parameter values.
} 
where:

$$
E=K_{h} \int_{\underline{\gamma_{h}}}^{\max \left\{\gamma_{h}^{A}, \gamma_{h}^{B}\right\}} g_{h}\left(\gamma_{h}\right) d \gamma_{h},
$$

and

$$
\begin{aligned}
D & =K_{h} \int_{\underline{\gamma}_{h}}^{\max \left\{\underline{\gamma}_{h}, \gamma_{h}^{A}\right\}}\left(n\left(\gamma_{h}, R, R_{f}^{D}\right)-1\right) g_{h}\left(\gamma_{h}\right) d \gamma_{h} \\
& +K_{h} \int_{\max \left\{\underline{\gamma}_{h}, \gamma_{h}^{A}\right\}}^{\max \left\{\gamma_{h}^{A}, \gamma_{h}^{B}\right\}}\left(n\left(\gamma_{h}, R, \phi R_{f}^{D}\right)-1\right) g_{h}\left(\gamma_{h}\right) d \gamma_{h}
\end{aligned}
$$

Proposition 3 The solution to equations 20 to 27 is unique.

Proof. See appendix A.

Equations (20) and (21) are clearing conditions of the market for financial intermediation in the home and the foreign country, respectively. Because banks in the home country raise deposits $D$ in the foreign country, foreign banks have to intermediate only $K_{f}-D$ units of capital. In turn, bankers in the home country that obtain additional funding from abroad, have to intermediate the domestic capital $K_{h}$ plus the additional capital $D$. Equivalently, the equity capital $E$ of bankers that raise funding in the foreign country, plus the funds intermediated by purely domestic home country banks, have to equal the home country's capital stock, a condition stated in equation 21. The remaining equations determine the bank entry cutoffs in the two countries $\gamma_{h}^{*}$ and $\gamma_{f}^{*}$, the cross-border borrowing cutoff $\gamma_{h}^{B}$ and the FDI cutoff $\gamma_{h}^{A}$. Together, the conditions constitute a system of six equations in six unknowns.

Because funding is cheaper in the foreign country than in the home country under autarky, home country banks expand abroad by raising funds from foreign depositors in the open economy. This leads to entry into banking at home and bank exit in the foreign country. As a result, the bank entry cutoff $\gamma_{h}^{*}$ moves up, while $\gamma_{f}^{*}$ declines. Deposit rates equilibrate but do not equate. A gap between funding costs $R_{h}^{D}-R_{f}^{D}>0$ in the open economy equilibrium remains which is smaller than under autarky but large enough to give home country banks an incentive to incur the fixed and variable costs to expand their operations to the foreign country. 
Banking sector integration has an effect on the size distribution of banks in both countries not only through changes in the bank entry cutoffs but also through changes in the size of individual banks. The more efficient home country banks that borrow from abroad, either cross-border or through FDI, can grow their balance sheets due to lower funding costs. The size of banks that only operate in the domestic market is also affected since deposit rates change. Foreign banks become smaller, while home country banks that operate only domestically also get bigger.

\subsection{Model simulation}

To further illustrate the key mechanisms of the model and to explore in detail the role of bank heterogeneity, I provide a numerical example. Bank-level data from the Deutsche Bundesbank, which is described and explored in detail in section 5, is used to select the parameters for the simulation. In the example, Germany corresponds to the home country, while the Czech Republic is the foreign country.

\subsubsection{Parameters}

The German bank-level dataset contains the ratio of overhead costs to total assets of roughly 2000 German banks in the year 2005, which is the preferred, inverse measure of efficiency used also later in the empirical analysis in section 5. Overhead costs comprise salaries, expenditures for office space, IT etc. and are independent of funding costs, consistent with the formulation of monitoring costs in the model.

Because the model assumes that each bank is endowed with one unit of equity capital, I adjust the bank-level dataset by multiplying each bank-level observation with bank equity and estimate the monitoring cost distribution based on this modified version. ${ }^{26}$ The resulting overhead cost distribution closely resembles the Pareto distribution. The shape parameter of the Pareto distribution estimated via Maximum Likelihood is $a=0.55 .{ }^{27}$ The minimum

\footnotetext{
${ }^{26}$ For example, a bank with an overhead cost ratio of 3 percent with 100 units of equity capital will show up as 100 observations each with a 3 percent ratio.

${ }^{27}$ I exploit the fact that when a Pareto distribution is truncted, the resulting distribution is also Pareto distributed and has the same shape parameter.
} 
value of the distribution $\underline{\gamma}_{G}$ is set to the average overhead costs of the 100 least efficient German banks, which results in $\underline{\gamma}_{G}=0.006317 .^{28}$

Information on capital-labor ratios and returns to capital are based on data from David et al. (2014). Values for the year 2000 are used to fix capital and labor endowments as well as TFP. ${ }^{29} \lambda$ and $\lambda_{L}$, the success probabilities of projects with and without monitoring are deep parameters of the model that govern the leverage of banks. The two parameters are set so as to ensure that the sufficient conditions from proposition 1 hold. Specifically, I set $\lambda$ equal to 0.9 and $\lambda_{L}$ to 0.85 .

In 2000, the Czech Republic had a similar marginal product of capital as Germany according to David et al. (2014), and it hosted less efficient banks than Germany based on information from the World Bank's Financial Development and Structure Dataset. The open economy equilibrium will therefore correspond to case where German (home) banks raise funding from Czech (foreign) banks and marginal products of capital equalize.

The monitoring cost distribution that Czech banks draw from has the same shape parameter as that of German banks $(a=0.55)$. The minimum value of the Pareto distribution, however, differs across countries. From the Financial Development and Structure Dataset, the difference between the average overhead costs of German and Czech banks was one percentage point in 2000. Accordingly, $\underline{\gamma}_{C}$ is set so that the average overhead costs of Czech banks are 1 percentage point higher than that of German banks in the closed economy. This implies $\underline{\gamma}_{C}=0.0103436$ or $\Delta=0.0040266$.

To solve for the open economy equilibrium, values for the fixed and variable costs that German banks face when operating in the Czech Republic $\left(\phi, f^{B}\right.$ and $\left.f^{A}\right)$ are also needed. Since only four German banks have affiliates in the Czech Republic in 2005, I do not model affiliate lending and set the fixed cost of FDI $f^{A}$ to a prohibitively high value. Furthermore, I assume $\phi=1.001$ and $f^{B}=0.24$. Table 1 summarizes the parameters for the simulation.

\footnotetext{
${ }^{28}$ The first and 99th percentile of the overhead costs distribution are dropped for this exercise.

${ }^{29}$ David et al. (2014) provide the capital stock and MPKs based on the method suggested by Caselli and Feyrer (2007) by which returns are computed using country specific prices of output, consumption and investment. I use additional data on the labor force and assume a Cobb-Douglas production function $Y=A K^{\alpha} L^{1-\alpha}$ with a capital share of $\alpha=0.3$ to back out A.
} 


\subsubsection{Autarky versus open economy}

Column (1) of table 2 shows the solution to the closed economy for Germany and the Czech Republic. The two countries have very similar gross returns to capital, while German banks have lower overhead costs. This implies that a smaller fraction of capitalists in Germany becomes bankers and that the average balance sheet size and leverage of active bankers are higher in Germany than in the Czech Republic. Accordingly, the German deposit rate is higher than the corresponding Czech rate in the closed economy.

Next, the open economy equilibrium is computed using conditions (20) to (25). ${ }^{30}$ Outcomes are presented in column (2) of table 2. German banks raise funding from Czech depositors when the two countries integrate and replace Czech banks as domestic financial intermediaries. The least efficient Czech banks exit. At the same time, there is entry into banking in Germany. Deposit rates equilibrate with the German deposit rate falling and the Czech deposit rate rising.

In equilibrium, around 4.5 percent of German banks borrow and lend from Czech residents. This implies that more than 59 percent of loans to Czech firms come from German banks. Note that the few German banks can have relatively high lending volumes in the host country because the Czech economy is much smaller than the German. Loans to Czech firms represent around 4.5 percent of German banks' total loans.

The opening up also has implications for banking sector concentration. The top chart of figure 2 depicts the balance sheet size of German banks as a function of their overhead costs. The dashed line shows the relationship in the closed economy, the solid line is for the open economy. Because German banks that borrow from Czech depositors pay lower interest, they can increase their balance sheet size. As a result, German banking sector concentration measured by the share of banking sector assets that are held by the top 10 percent of the banks increases. ${ }^{31}$ Due to exit by the smallest Czech banks, the concentration of the Czech

\footnotetext{
${ }^{30}$ With only small differences in autarky marginal products of capital, the equilibrium is determined by these conditions together with the condition $R_{f}=R_{h}$, which pins down the net capital flow.

${ }^{31}$ Janicki and Prescott (2006) document changes in the size distribution of U.S. banks from 1960 to 2005. Consistent with the theory in this paper, they show that over time a higher fraction of banking sector assets is held by a small number of large banks. See McCord et al. (2014) for an update of Janicki's and Prescott's study.
} 
banking sector goes down. ${ }^{32}$

Because marginal products of capital across countries in the closed economy are not identical, there is a small net capital flow (-0.00108) from the Czech Republic to Germany so that MPKs across the two countries equate. German banks borrow on net from Czech residents. Importantly, net capital flows are not equal to gross capital flows. German banks export equity capital. This capital outflow must be offset by an import of deposits from the Czech Republic by German banks to keep gross returns equalized. The model thus generates two-way capital flows and explains why capital may flow into a county in the form of financial sector FDI and might leave again as depositor capital. The equilibrium gross deposit flow from the Czech Republic to Germany corresponds to roughly 9.4 percent of Czech deposits.

Welfare in both countries increases, defined as the sum of the return to workers, bank profits and deposits paid. While banking sector profits are shifted from the Czech Republic (65 percent) to Germany ( +5.4 percent), the Czech economy gains overall because monitoring costs are reduced and, hence, depositors are paid almost 20 percent more compared to the closed economy. The relative welfare gain is significantly bigger for the Czech Republic than for Germany.

\subsubsection{Role of heterogeneity}

Two experiments make clear that bank heterogeneity matters. In each experiment, the shape parameter of the Pareto distribution for German banks is set to $a=0.75$; that is, the distribution of monitoring costs features less heterogeneity (is less dispersed) than in the baseline. In the first case, $\underline{\gamma}_{G}$ is set so that the closed economy deposit rate $R_{G}^{D}$ in Germany is unchanged. In the second case, $\underline{\gamma}_{G}$ is chosen so that the average overhead costs of German banks are the same as in the baseline closed economy $\left(\underline{\gamma}_{G}=0.0065267\right)$.

Consider the first case. Keeping the German closed economy deposit rate constant in the face of less bank heterogeneity means that the lower bound of the overhead cost distribution must move up (to $\underline{\gamma}_{G}=0.0066995$ ). As a result, the share of German capitalists that become bankers increases, while the average size of German banks decreases. Because the

\footnotetext{
${ }^{32}$ The concentration measure is computed without taking lending by foreign banks into account.
} 
Czech economy now integrates with an economy with slightly less efficient banks, the open economy deposit rate in the Czech Republic remains below that of the baseline scenario. Fewer German banks raise funding in the country and fewer bank profits are shifted to Germany. The welfare gains from integration are lower.

In the second case, the average overhead costs of German banks under autarky are unchanged. With less heterogeneity but the same average overhead costs, the lower bound of the Pareto distribution also must move up $\left(\underline{\gamma}_{G}=0.0065267\right)$. The closed economy bank entry cutoff $\gamma_{G}^{*}$ moves down and hence the German closed economy deposit rate is higher than in the baseline. For the open economy equilibrium, this implies that the fraction of German banks that borrow from Czech depositors increases. The Czech equilibrium deposit rate and welfare gains for the Czech Republic are higher.

These experiments demonstrate that the open economy equilibrium and the welfare gains from integration depend on the exact monitoring cost distribution of banks in the two countries. Bank heterogeneity, which is a key feature of the data as section 5 shows, matters also in theory. The framework in Niepmann (2015), which analyzes banking across borders in a model with a representative banking sector, delivers identical welfare gains when the observed closed economy average intermediation costs and deposit rates in the integrating countries are the same.

\subsection{Comparative statics}

The data from the Deutsche Bundesbank provides information on the foreign operations of individual German banks across foreign countries. On the one hand, these data can be used to test corollary 1 of the model, which relates bank efficiency to the intensive and extensive margins of banking across borders. On the other hand, the data can shed light on how German banks' activities vary across foreign countries. Motivated by the data, the focus in this section is on analyzing how the open economy equilibrium varies with the characteristics of the foreign country, keeping home country characteristics fixed. While the model does not have a closed form solution, implicit functions theorems can be used to derive the comparative statics around an interior equilibrium analytically. 
The effects of foreign country size Consider first an increase in the size of the foreign country, reflected in a higher endowment of this country that leaves its capital-labor ratio unaffected so that $R_{f}=R_{h}=R$ continues to hold. With a bigger foreign country, the same volume of deposits intermediated by home country banks implies a higher foreign deposit rate. As a result, more home bankers find it profitable to obtain funding abroad. The crossborder borrowing cutoff $\gamma^{B}$ and the FDI cutoff $\gamma^{A}$ move up. The foreign asset and liability holdings of the home country banking sector increase (see Proposition 4).

Proposition 4 When the foreign country increases in size reflected in a proportional increase of $K_{f}$ and $L_{f}$ (leaving the country's capital-labor ratio unaffected), the cross-border borrowing cutoff $\gamma^{B}$, the FDI cutoff $\gamma^{A}$ as well as foreign liabilities $d_{f h}$ of individual home country banks increase. ${ }^{33}$

Proof. See appendix A.

The effects of foreign banking sector efficiency Next, assume that the foreign banking sector becomes less efficient, reflected in an increase in $\Delta$. As a consequence, the difference in autarky deposit rates between the two countries rises. Lower funding costs in the foreign country relative to the home country provide larger incentives for home banks to expand abroad and borrow from depositors there. Therefore, the cross-border borrowing cutoff $\gamma^{B}$ and the FDI cutoff $\gamma^{A}$ increase. Banks from the home country hold more foreign assets and liabilities in equilibrium. Proposition 5 summarizes this result.

Proposition 5 When the efficiency of the foreign banking sector decreases, reflected in an increase in $\Delta$, the cross-border borrowing cutoff $\gamma^{B}$, the FDI cutoff $\gamma^{A}$ as well as foreign liabilities $d_{f h}$ of individual home country banks increase. ${ }^{34}$

Proof. See appendix A.

\footnotetext{
${ }^{33}$ In the model with $\tau=1$, the foreign assets of individual home country banks are not determined. However, in equilibrium, $D=A$, where $A$ denotes the total foreign assets of home country banks. So total assets of home banks abroad increase in foreign country size.

${ }^{34}$ See footnote 23 .
} 
The effects of barriers to bank entry and cross-border frictions Finally, the effects of changes in the fixed and variable costs of foreign operations are presented. With a higher variable cost $\phi$ and a higher fixed cost of cross-border borrowing $f^{B}$, fewer home country banks find it optimal to borrow from depositors abroad. As a consequence, the borrowing cutoff $\gamma^{B}$ goes down. An increase in the fixed cost of FDI has the opposite effect. The higher $f^{A}$, the fewer banks invest in FDI and the less capital in the foreign country is intermediated by home country banks. This means a lower foreign deposit rate ceteris paribus and thus increased incentives for home country banks to engage in cross-border borrowing. The cross-border borrowing cutoff $\gamma^{A}$ therefore increases in $f^{A}$. These results, summarized in proposition 6 , resemble the classic proximity-concentration tradeoff prominent in international trade theory (see Helpman et al. (2004)).

Proposition 6 (i) When the variable cost of cross-border borrowing $\phi$ increases, the crossborder borrowing cutoff $\gamma^{B}$ decreases and the FDI cutoff $\gamma^{A}$ increases. (ii) When the fixed cost of cross-border borrowing $f^{B}$ increases, the cross-border borrowing cutoff $\gamma^{B}$ decreases and the FDI cutoff $\gamma^{A}$ increases.

(iii) When the fixed cost of establishing a foreign affiliate $f^{A}$ increases, the cross-border borrowing cutoff $\gamma^{B}$ increases and the FDI cutoff $\gamma^{A}$ decreases.

Proof. See appendix A. - Empirical evidence in support of the predictions stated in propositions 4 to 6 is provided in section 5 .

\subsection{Solution to the general model}

When countries differ both in autarky returns to capital and banking sector efficiencies, the equilibrium can take different forms. ${ }^{35}$ The numerical example presented in the previous section illustrates what happens when relative factor endowments and production technologies differ only slightly across countries. Because banks that have incurred the fixed costs $f^{B}$ or $f^{A}$ are free to invest at home and abroad, they will invest in the country with the higher return to capital. If the volume of capital that these banks can channel across border is

\footnotetext{
${ }^{35}$ This does not mean that there are multiple equilibria. Instead the equilibrium is characterized by a different set of equations.
} 
large enough, gross returns to capital will equate and the equilibrium will be characterized by conditions (20) to (25) with the addition that the net capital flow $K_{f h}$ is not zero but determined by $R_{f}=R_{h}$. When the home country is capital scarce relative to the foreign country, home country banks will import capital; otherwise, they will export capital to the foreign country. The comparative statics derived previously continue to hold even with small differences in relative factor endowments and production technologies.

When the home country has much more capital relative to labor than the foreign country or operates an inferior production technology, some banks, for which the cost of cross-border borrowing or FDI is too high, may find it profitable to incur the smaller fixed cost of crossborder lending. An equilibrium is possible where the less efficient home country banks lend cross-border to firms abroad while the more efficient banks both lend to and borrow from abroad (cross-border and through foreign affiliates). In such an equilibrium, $R_{h}^{D}>R_{f}^{D}$, $R_{f}>R_{h}$ and $\gamma^{B}<\gamma^{L} .{ }^{36}$

In appendix $\mathrm{B}$, the model is solved for $\tau=\phi=1$ and varying capital-labor ratios and banking sector efficiencies in the two countries. The simulation illustrates the different cases that are possible in general. Niepmann (2015) analyzes different equilibrium cases in a model without bank heterogeneity and derives the full comparative statics of that model within and across equilibrium cases. The intuition of that simpler framework carries over to the model presented in this paper. Essentially, the direction of net capital flows is a function of countries' relative factor endowments/technologies. Which banks/banking sector channel capital across borders and gross capital flows are determined by relative bank efficiencies. More details can be found in appendix B.

\section{Empirical Analysis}

The proposed model is consistent with key patterns in the data. Based on German banklevel data, I document the following results. First, more efficient banks are larger and more levered. Second, banks sort into foreign activities based on their efficiency. Conditional

\footnotetext{
${ }^{36}$ In an earlier version of this paper, Niepmann (2013), another case is analyzed in detail where both banking sectors (home and foreign) operate abroad. Home country banks borrow from abroad for investment at home, while banks in the foreign country use domestic deposits to invest in the home country.
} 
on operating abroad, those with higher overhead costs relative to their assets have lower volumes of foreign activity. Third, country characteristics affect banks' foreign activities in the predicted way; that is, banks are more likely to operate abroad, the larger the foreign country, the lower foreign banking sector efficiency and the lower cross-border frictions and barriers to bank entry are. The extensive and intensive margins of banking across borders co-vary so strongly with bank efficiency and host country characteristics that more than 50 percent of the variation in the cross-border lending, borrowing and FDI cutoffs across countries is explained by host country size, host banking sector efficiency and cross-border frictions.

\subsection{Data}

The Deutsche Bundesbank collects detailed information on the foreign activities of German banks in a report called "External Position of Banks". These data allow one to determine, for each German bank $k$ and foreign country $i$, whether the bank operates in country $i$ and, if yes, whether through local affiliates or cross-border by borrowing and/or lending from country $i$ residents. The volume of foreign assets and liabilities on the balance sheet of parent banks as well as their affiliates is observed, too. ${ }^{37}$ The full dataset with information for the universe of German banks and their operations in 178 countries is available to me for 2005. In that year, there are 1,999 banks, the majority being cooperative savings banks $(1,292)$, savings banks (463) or commercial banks (105). These data are matched with balance sheet and income and loss data, also available at the Deutsche Bundesbank. ${ }^{38}$

Two different simple proxies for bank efficiency are employed: a bank's overhead costs (the preferred measure) and its labor productivity (for robustness). ${ }^{39}$ The former measure is

\footnotetext{
${ }^{37}$ For a detailed description of the data source, see Fiorentino et al. (2010) and Buch et al. (2011).

${ }^{38}$ The data come at a monthly frequency, which I average over 12 months. Research Data and Service Centre of the Deutsche Bundesbank, External Position of Banks (AUSTA - "Auslandsstatus der Banken"), Monthly Balance Sheet Statistics (BISTA - "Monatliche Bilanzstatistik") and Income and Loss Data ("Gewinn und Verlustrechnung der Banken", 2005.

${ }^{39}$ In the banking literature, there is no consensus on how to measure the efficiency of banks. For discussions, see, e.g., Berger and Mester (1997), Hughes and Mester (2008). I experimented with additional measures of bank efficiency obtained from stochastic frontier analysis. Because these were highly correlated with the simpler accounting ratios but much noisier, I decided to stick with transparent, easier-to-interpret accounting ratios.
} 
calculated as a bank's overhead costs, which comprise salaries, expenditures for office space, IT etc., divided by its total assets. The latter measure is computed as the average size of bank $k$ 's balance sheet over the number of employees. ${ }^{40}$ Overhead costs to total assets and labor productivity are highly negatively correlated with a correlation coefficient of 93 percent.

The dataset with bank-level information is complemented by variables capturing relevant country $i$ characteristics described in detail below. As income and loss data is not available for all banks in the sample and as host country variables are only observed in a limited number of countries, the sample size reduces depending on the exact specification.

\subsection{Overview of German banks' foreign operations}

1,980 (1,975) of the 1,999 banks in the 2005 sample have some foreign assets (foreign liabilities) but only 52 or 2.6 percent of them have one or more foreign affiliates, which include both branches and subsidiaries. German banks hold foreign assets (foreign liabilities) in 177 (178) foreign countries but operate affiliates in only 58. There are many countries in which only a few banks are active while there are only a few countries in which practically all banks operate. Figure 3 illustrates this. The top chart plots the number of banks that have assets in a given country against the number of countries in which at least that many banks have assets. For example, there are 21 countries in which at least 540 banks are active. The middle and bottom charts show the same plot but for liabilities and affiliates.

Similarly, there are only a few banks that are active in many countries. The top chart of figure 4 shows the number of countries in which a bank has assets plotted against the number of banks that have assets in at least as many countries. The middle and bottom chart show the equivalent plot for the number of banks with liabilities and affiliates in foreign countries.

Among those countries with the largest number of active German banks, are, unsurprisingly, the United States, Great Britain, Switzerland, Luxembourg, and Austria. Assets and liabilities are highly concentrated in a few locations. Around 50 percent of all foreign assets in 2005 were held in Great Britain, the United States and France alone.

\footnotetext{
${ }^{40}$ Income and loss data and data on the number of employees is for the parent bank including its branches abroad. Subsidiaries are excluded. Data for parent banks only is not available.
} 


\subsection{Relationship between bank size, efficiency and leverage}

Before analyzing the foreign activities of German banks in detail, I present evidence that the relationship between bank size, leverage and efficiency proposed by the model holds in the data. According to the theory, banks with lower monitoring costs $\gamma$ should be larger and more levered. Table 3 shows that the data support this. It presents results from regressions of $\log$ bank size on log equity and log overhead costs. Based on the estimated coefficients in columns (1) and (2), a bank's balance sheet increases one for one with its equity. At the same time, its size, controlling for its equity, declines with its overhead costs and increases with its labor productivity, implying that banks with lower overhead costs or a higher labor productivity exhibit a higher leverage as modeled.

\subsection{Efficiency as a predictor of a bank's foreign activities}

Corollary 1 states that banks with lower monitoring costs are more likely to operate abroad and, conditional on operating abroad, have larger foreign operations. To examine the relationship between efficiency and the extensive margin formally in addition to the graphical illustration in figure 1, I estimate several logit specifications in columns (1) to (3) of table 4. In column (1), the dependent variable takes value 1 if a bank $k$ has cross-border assets, in column (2), if it has cross-border liabilities and, in column (3), if it has FDI in a given country $i$.

In addition, I test for the effects of size and efficiency on the volume of banks' foreign operations using OLS regressions. In columns (4) and (6) of table 4, the dependent variables are the log cross-border assets and liabilities, respectively, of bank $k$ in country $i$. In column (5) (column (7)), the log assets (liabilities) on the balance sheets of foreign affiliates are used as the regressand. ${ }^{41}$ Each of the dependent variables is regressed on the log ratio of overhead costs to total assets. All specifications include country-fixed effects and dummies for the type of bank. ${ }^{42}$ Standard errors are clustered at the bank level.

\footnotetext{
${ }^{41}$ In this case, assets (liabilities) correspond to the positions of all affiliates of bank $k$ located in country $i$ toward residents of country $i$ (so called local assets (liabilities)). They comprise only the local business of the affiliates excluding the activities that these entities conduct with residents from other countries.

${ }^{42}$ Nine dummy variables indicate whether an entity is a i) commercial bank, ii) state bank, iii) savings bank, (iv) cooperative central bank, v) cooperative savings bank, vi) building credit society, vii) bank with
} 
The highly significant regression coefficients in columns (1) to (3) show that the probability that a bank has foreign assets, foreign liabilities or affiliates abroad decreases with its overhead costs. Moreover, as shown in columns (4) to (6), banks with higher overhead costs hold fewer foreign assets and liabilities on their balance sheets. The evidence of a negative effect of overhead costs on the volume of assets and liabilities held on the balance sheets of foreign affiliates is weaker (columns (5) and (7)), most likely due to the small number of observations.

\subsection{The role of host country characteristics}

Logit regressions The model does not only predict how the intensive and extensive margins of banks' foreign operations vary with bank efficiency but also how they vary with host country characteristics. Table 5 summarizes the model predictions formulated in propositions 4, 5 and 6. Niepmann (2015) documents that the assets and liabilities of German banks in the foreign non-bank private sector increase with the average overhead costs of banks in the host country as well as with the GDP of the host market. ${ }^{43}$ The focus of the analysis in this paper is therefore on the extensive margin of banks' foreign activities.

Efficiency of the banking sector in the foreign country is proxied as in Niepmann (2015) by the average overhead costs to total assets of all banks residing in the country. This measure comes from the World Bank's Financial Development and Structure Dataset (Beck et al. (2006)). As it is endogenous to the operations of foreign banks because it is computed including them, the variable is lagged by 5 years. ${ }^{44}$ Variable transaction costs are proxied by distance of the foreign country from Germany. Financial freedom, which, among other things, captures bank entry barriers, and foreign countries' bureaucratic quality are used as proxies for fixed costs. ${ }^{45}$ Ideally, one would like to have separate measures for the fixed cost

special functions, viii) savings and loan association, ix) other.

${ }^{43}$ See table 1 in Niepmann (2015).

${ }^{44}$ Going further back in time would be desirable but information on overhead costs is only available in the database starting from 1998.

${ }^{45}$ The Financial Freedom Index scores an economys financial freedom by looking into the following five broad areas: the extent of government regulation of financial services, the degree of state intervention in banks and other financial firms through direct and indirect ownership, the extent of financial and capital market development, Government influence on the allocation of credit, and openness to foreign competition. A country's bureaucratic quality score reflects the strength and expertise of the domestic bureaucracy to 
of cross-border operations and the fixed cost of FDI. These are, unfortunately, not available, which limits the extent to which proposition 6 can be tested. ${ }^{46}$ Overhead costs, GDP, GDP per capita as well as distance enter the regression in logs. I also control for differences in countries' capital-labor ratios and productivities using information on marginal products of capital from David et al. (2014). ${ }^{47}$ A country's marginal product of capital is endogenous to foreign borrowing and lending so this measure is also lagged by five years. ${ }^{48}$

To test whether the extensive margin predictions hold, I run logit regressions. Similar to table 5, the dependent variables in table 6 take the value of 1 if a bank has cross-border assets (column 1), liabilities (column 2) or at least one affiliate (column 3) in country $i$, respectively. All regressions includes bank-fixed effects. ${ }^{49}$ Standard errors are clustered at the country level.

Consistent with the predictions formulated in propositions 4 and 5, the probability that a bank has cross-border assets or cross-border liabilities in a host country increases with the average overhead costs of the local banking sector and with the country's GDP. For the establishment of affiliates, GDP of the host country also plays the expected role, while overhead costs are not significant.

Financial freedom, distance and bureaucratic quality are all likely correlated with both the variable and fixed costs associated with cross-border operations and the establishment of affiliates abroad. Accordingly, the probability that banks hold cross-border assets, crossborder liabilities or have affiliates in a host country all increase with the host country's financial freedom and decrease with the host country's distance from Germany. Bureaucratic quality also has the expected sign but is only significant in column (1) where cross-border assets are used. GDP per capita is not significant at standard significance levels. The coefficient associated with the MPK variable is significant and has a positive sign in column (1), which indicates that the probability that German banks have cross-border assets in

govern without drastic changes in policy or interruptions in government services.

${ }^{46}$ I included many different proxies for fixed costs, for example, a measure of bank entry barriers from Detragiache et al. (2008). Estimated coefficients always had the expected signs but there was little indication that any of those measures was suited to distinguish between the costs of cross-border operations and FDI.

${ }^{47}$ See footnote 19 and the data appendix for more details.

${ }^{48}$ For more details on variables and data sources, see the data appendix.

${ }^{49}$ Regression results are quantitatively and qualitatively the same when controls for bank size and bank type are included instead of bank fixed effects. 
a market increases with that country's marginal product of capital, which signals higher returns to capital there. ${ }^{50}$

Cutoff regressions Combining the results on host country characteristics with those on bank efficiency, we can conclude that the efficiency of banks that have cross-border assets and liabilities in a given market increases with the host country's banking sector efficiency, its distance to Germany and decreases with its GDP, financial freedom and bureaucratic quality. To illustrate this and to shed light on how strong banks' sorting on host country characteristics is, I run another set of regressions. The focus is on the behavior of the different cutoffs measured by the least efficient bank (that with the highest overhead costs) that holds cross-border assets, liabilities or has an affiliate in a given market. ${ }^{51}$ In particular, the log of the overhead costs of the cutoff bank is regressed on host country variables. As an alternative to the log of the overhead costs of the least efficient bank, I also employ the average overhead costs of all banks active in a given market as the dependent variable.

Table 7 shows the result of this exercise. Note that there is one observation for each country in the underlying samples. Column (1), (3) and (5) of table 6 display the estimated coefficients when the dependent variable reflects the overhead costs of the least efficient banks (maximum overhead costs). Column (2), (4) and (6) present the coefficients when the dependent variable captures the average overhead costs of all banks operating in country $i$. With the exception of the coefficient on the marginal product of capital, all estimated coefficients are highly significant and consistent with the model predictions. The positive coefficient on host country overhead costs in column (1) implies that the overhead costs of the least efficient German bank that holds positive cross-border assets in a country increases with the overhead costs of that country's banking sector. In other words, the more efficient the foreign banking sector, the more efficient is the least efficient German bank (the cutoff bank) that operates there. The estimates related to distance, financial openness and bureaucratic quality indicate that lower cross-border frictions decrease the efficiency of the cutoff bank. Similarly, the larger the host market is, the lower the efficiency of the cutoff bank is.

\footnotetext{
${ }^{50}$ The sign of the coefficient is consistent with the theory. The incentives of banks to invest in a foreign countries increase with the return to capital there.

${ }^{51}$ This analysis is similar to Yeaple (2009), who considers sorting of manufacturing firms into FDI.
} 
Column (2) confirms these results for average overhead costs. Columns (3) and (4) show the same patterns for the cross-border lending cutoff. Results for the FDI cutoff are weaker, probably due to the small sample size with a total of 38 observations. Only the distance coefficient is significant showing the expected sign. Note that all results also hold when instead of overhead costs labor productivity or the balance sheet size of banks is used to determine the cutoff banks. ${ }^{52}$

One of the main takeaways from table 7 is the $R^{2}$, which is remarkably high throughout. More than 60 percent of the variation in the lending, borrowing and FDI cutoffs is explained by the covariates. To illustrate the high predictive power of the different variables, figure 5 plots the average overhead costs of banks that have positive cross-border assets (triangle), cross-border liabilities (square) or affiliates (circle) in a country against countries' log GDP, log distance from Germany and bureaucratic quality, respectively. Even without conditioning on other variables, there is a strong relationship between these country characteristics and the average overhead costs of German banks that operate there.

\section{Conclusions}

While many banks today operate across borders and the implications are intensely debated, the academic literature has only recently started to explore this phenomenon. ${ }^{53}$ This paper provides a tractable model of banking across borders with heterogeneous banks to study the drivers and the implications of banks' foreign activities that is consistent with key patterns in the data. Several conclusions can be drawn.

First, while the modeled relationship between bank efficiency and foreign activity can also be generated in alternative frameworks with corresponding cost structures, sorting with respect to host country characteristics is a unique feature of the model. The fact that the ratio of overhead costs to total assets of the least efficient German bank that operates in a foreign country decreases with the overhead costs of banks in that country strongly supports

\footnotetext{
${ }^{52}$ They also hold when instead of total assets and liabilities only liabilities in the non-bank private sector are taken into account when constructing the cutoffs.

${ }^{53}$ For policy issues around cross-border banking, see Committee on the Global Financial System (2010) and Allen et al. (2011) for example.
} 
the trade approach to banking across borders and suggests that differences in the cost of financial intermediation and bank efficiencies are a key driving factor.

Second, the sorting of banks into foreign activities also indicates that banks have to incur substantial fixed costs to operate abroad. Only larger banks are able to overcome these costs, channel capital across borders and potentially supply low cost intermediation services to entrepreneurs and depositors in foreign markets. Internationally active banks are necessarily larger than purely domestic banks and globalization tends to make them even larger.

Finally, bank-level heterogeneity is relevant. The distributions of bank size and efficiency of the integrating banking sectors influence how banking sector integration affects net interest rate margins, net and gross capital flows and welfare. Future open economy models of financial intermediation should take this heterogeneity into account.

In the theoretical framework presented, a single bank either invests abroad or at home. Similarly, it either raises deposits at home or abroad. This would be altered if the success of firms was not perfectly correlated and capitalists were risk averse, for example. Another characteristic of the model is that banks are capacity constrained. As a consequence, the volume of foreign lending and borrowing adjusts primarily through the extensive margin. This would change if equity was traded. Introducing diversification into the model and allowing for mergers and acquisitions are promising avenues for future research.

Friederike Niepmann, Board of Governors of the Federal Reserve System and CESifo Munich. 


\section{A Proofs}

\section{Proof of Proposition 1}

The bank entry cutoff is the solution to the following equation:

$$
1=\int_{\underline{\gamma}}^{\gamma^{*}} \underbrace{\frac{\left(R-\frac{\gamma^{*}}{\lambda}\right)\left(\lambda-\lambda_{L}\right)}{\gamma-\left(\lambda-\lambda_{L}\right) \frac{\gamma^{*}}{\lambda}}}_{n(\gamma)} g(\gamma) d \gamma .
$$

The RHS of the equation is continuously increasing in $\gamma^{*}$. Thus if a solution to A.1 exists, it

is unique. For $\gamma^{*}=\underline{\gamma}$, the RHS of the above equation is 0 . For a solution to exist, we thus need that:

$$
\lim _{\gamma^{*} \rightarrow \underline{\gamma /\left(1-\lambda_{L} / \lambda\right)}} \int_{\underline{\gamma}}^{\gamma^{*}} \frac{\left(R-\frac{\gamma^{*}}{\lambda}\right)\left(\lambda-\lambda_{L}\right)}{\gamma-\left(\lambda-\lambda_{L}\right) \frac{\gamma^{*}}{\lambda}} g(\gamma) d \gamma>1 .
$$

The following two conditions are sufficient for the above condition on the limit to hold:

$$
\int_{\underline{\gamma}}^{\gamma=R\left(\lambda-\lambda_{L}\right)} \frac{1}{1-\frac{\lambda}{\lambda_{L}}+\frac{\gamma \lambda}{\left(\lambda-\lambda_{L}\right) \lambda_{L} R}} g(\gamma) d \gamma>1
$$

and

$$
\underline{\gamma}>\left(\lambda-\lambda_{L}\right) R\left(1-\frac{\lambda_{L}}{\lambda}\right)
$$

\section{Proof of Proposition 2}

$\pi\left(-R, \tilde{R}^{D}, \gamma\right)$ is supermodular in $-R$ and $\gamma$ and in $\tilde{R}^{D}$ and $\gamma$. Supermodularity of $\pi(-R, \gamma)$ corresponds to $\pi_{-R, \gamma}>0$.

$$
-\frac{\partial \pi^{2}}{\partial-R \partial \gamma}=\frac{\tilde{R}^{D}\left(\lambda-\lambda_{L}\right) \lambda_{L}}{\left(\tilde{R}^{D}\left(\lambda-\lambda_{L}\right)-R\left(\lambda-\lambda_{L}\right)+\gamma\right)^{3}}\left(-R^{D}\left(\lambda-\lambda_{L}\right)+R\left(\lambda-\lambda_{L}\right)+\gamma\right)
$$

The first term, the fraction, is positive given that $v(\gamma)$ is positive. The second term in brackets is also positive if $\tilde{R}^{D}<R$. Both conditions hold in equilibrium. Therefore $\pi_{-R, \gamma}>$ 0 . 
Supermodularity of $\pi\left(\tilde{R}^{D}, \gamma\right)$ corresponds to $\pi_{\tilde{R}^{D}, \gamma}>0$.

$$
-\frac{\partial \pi^{2}}{\partial \tilde{R}^{D} \partial \gamma}=\frac{\lambda_{L}\left(\lambda-\lambda_{L}\right)}{\left(\tilde{R}^{D}\left(\lambda-\lambda_{L}\right)-R\left(\lambda-\lambda_{L}\right)+\gamma\right)^{3}}\left(\left(R\left(\lambda-\lambda_{L}\right)-\gamma\right)\left(R-\tilde{R}^{D}\right)+\gamma \tilde{R}^{D}\right) .
$$

The first term, the fraction, is positive given that $v(\gamma)$ is positive. The second term in brackets is also positive if $\tilde{R}^{D}<R$ and $R\left(\lambda-\lambda_{L}\right)-\gamma>0$. The three conditions hold in equilibrium. Therefore $\pi_{\tilde{R}^{D}, \gamma}>0$.

Assume $R_{j}<R_{i}$. Supermodularity of $\pi(-R, \gamma)$ implies that for any two bankers of type $\gamma_{1}$ and $\gamma_{2}<\gamma_{1}$ :

$$
\begin{aligned}
& & \pi\left(R_{j}, \gamma_{1}\right)-\pi\left(R_{j}, \gamma_{2}\right) & >\pi\left(R_{i}, \gamma_{1}\right)-\pi\left(R_{i}, \gamma_{2}\right) \\
\Rightarrow & & \pi\left(R_{i}, \gamma_{2}\right)-\pi\left(R_{j}, \gamma_{2}\right) & >\pi\left(R_{i}, \gamma_{1}\right)-\pi\left(R_{j}, \gamma_{1}\right) \\
\Rightarrow & & \pi\left(R_{i}, \gamma_{2}\right)-f_{i j}^{L}-\pi\left(R_{j}, \gamma_{2}\right) & >\pi\left(R_{i}, \gamma_{1}\right)-f_{i j}^{L}-\pi\left(R_{j}, \gamma_{1}\right) \\
\Rightarrow & & \pi_{i j}^{X}\left(\gamma_{2}\right)-\pi_{j j}^{X}\left(\gamma_{2}\right) & >\pi_{i j}^{X}\left(\gamma_{1}\right)-\pi_{j j}^{X}\left(\gamma_{1}\right) .
\end{aligned}
$$

This relationship holds for any pair of bankers. Let $\gamma_{j}^{L}$ denote the banker who is indifferent between investing at home and abroad. If some bankers invest abroad while others invest

only at home, then this implies that all bankers of type $\gamma_{j} \leq \gamma_{j}^{L}$ invest abroad while all bankers for whom $\gamma_{j}>\gamma_{j}^{L}$ invest at home. The logic is analogous for cross-border borrowing and operations through foreign affiliates.

\section{Proof of Proposition 3}

The uniqueness of an interior equilibrium is proven as follows. It is shown that equation 21 can be expressed only as a function of $\gamma_{h}^{*}$ so that the RHS of the equation is continuously increasing in $\gamma_{h}^{*}$. Under the sufficient condition that

$$
\lim _{\gamma_{h}^{*} \rightarrow \underline{\gamma_{h}} /\left(1-\lambda_{L} / \lambda\right)} \int_{\underline{\gamma_{h}}}^{\gamma_{h}^{*}} \frac{\left(R-\frac{\gamma_{h}^{*}}{\lambda}\right)\left(\lambda-\lambda_{L}\right)}{\gamma_{h}-\left(\lambda-\lambda_{L}\right) \frac{\gamma_{h}^{*}}{\lambda}} g\left(\gamma_{h}\right) d \gamma_{h}>1
$$

the RHS cuts the LHS of the equation once. 
Consider again equation 21:

$$
K_{h}=K_{h} \int_{\underline{\gamma_{h}}}^{\max \left\{\gamma_{h}^{F}, \gamma_{h}^{B}\right\}} g_{h}\left(\gamma_{h}\right) d \gamma_{h}+K_{h} \int_{\max \left\{\gamma_{h}^{F}, \gamma_{h}^{B}\right\}}^{\gamma_{h}^{*}} n\left(\gamma_{h}, R, R_{h}^{D}\right) g_{h}\left(\gamma_{h}\right) d \gamma_{h}
$$

From equations 22 and $23, R_{f}^{D}=R-\gamma_{1}^{*} / \lambda$ and $R_{h}^{D}=R-\gamma_{h}^{*} / \lambda$. Therefore $\partial n\left(\gamma_{h}, R, R_{h}^{D}\right) / \partial \gamma_{h}^{*}>$ 0 . Because $n\left(\gamma_{h}, R, R_{h}^{D}\right)>1$, the RHS of equation 21 increase in $\gamma_{h}^{*}$ if:

$$
\frac{d \max \left\{\gamma_{h}^{F}, \gamma_{h}^{B}\right\}}{d \gamma_{h}^{*}}=\frac{\partial \max \left\{\gamma_{h}^{F}, \gamma_{h}^{B}\right\}}{\partial \gamma_{h}^{*}}+\frac{\partial \max \left\{\gamma_{h}^{F}, \gamma_{h}^{B}\right\}}{\partial \gamma_{f}^{*}} \frac{d \gamma_{f}^{*}}{d \gamma_{h}^{*}}<0
$$

Note that equations 24 and 25 give unique solutions to the cutoffs $\gamma_{h}^{B}$ and $\gamma_{h}^{A}$ for permissible parameter values. The following partial derivatives are easy to derive using implicit function theorems: $\frac{\partial \gamma^{B}}{\partial \gamma_{h}^{*}}<0, \frac{\partial \gamma^{B}}{\partial \gamma_{f}^{*}}>0, \frac{\partial \gamma^{A}}{\partial \gamma_{f}^{*}}>0, \frac{\partial \gamma^{A}}{\partial \gamma_{h}^{*}} \leq 0$. Now consider again equation 20:

$$
K_{f}=K_{f} \int_{\underline{\gamma_{f}}}^{\gamma_{f}^{*}} n\left(\gamma_{f}, R, R_{f}^{D}\right) g_{f}\left(\gamma_{f}\right) d \gamma_{f}+D
$$

with

$$
\begin{aligned}
D & =K_{h} \int_{\underline{\gamma}_{h}}^{\max \left\{\underline{\gamma}_{h}, \gamma_{h}^{F}\right\}}\left(n\left(\gamma_{h}, R, R_{f}^{D}\right)-1\right) g_{h}\left(\gamma_{h}\right) d \gamma_{h} \\
& +K_{h} \int_{\max \left\{\underline{\gamma}_{h}, \gamma_{h}^{F}\right\}}^{\max \left\{\gamma_{h}^{F}, \gamma_{h}^{B}\right\}}\left(n\left(\gamma_{h}, R, \phi R_{f}^{D}\right)-1\right) g_{h}\left(\gamma_{h}\right) d \gamma_{h} .
\end{aligned}
$$

This equation implicitly gives $\gamma_{f}^{*}\left(\gamma_{h}^{*}\right)$ and implies:

$$
\frac{d \gamma_{f}^{*}}{d \gamma_{h}^{*}}=\frac{\partial \gamma_{f}^{*}}{\partial D} \frac{d D}{d \gamma_{h}^{*}}
$$

where $\frac{\partial \gamma_{f}^{*}}{\partial D}<0$

$$
\frac{d D}{d \gamma_{h}^{*}}=\frac{\partial D}{\partial \gamma_{h}^{*}}+\frac{\partial D}{\partial \gamma_{f}^{*}} \frac{d \gamma_{f}^{*}}{d \gamma_{h}^{*}}
$$

Because $\frac{\partial \gamma_{h}^{B}}{\partial \gamma_{h}^{*}}<0, \frac{\partial \gamma_{h}^{A}}{\partial \gamma_{h}^{*}}<0$ and $n\left(\gamma_{h}, R, R_{f}^{D}\right)>n\left(\gamma_{h}, R, \phi R_{f}^{D}\right)$, it follows that $\frac{\partial D}{\partial \gamma_{h}^{*}}<0$. Also, $\frac{\partial D}{\partial \gamma_{f}^{*}}>0$.

$\frac{d D}{d \gamma_{h}^{*}}$ must then be negative by contradiction. Suppose $\frac{d D}{d \gamma_{h}^{*}}$ was positive. This would 
imply that $\frac{d \gamma_{f}^{*}}{d \gamma_{h}^{*}}$ was negative. Plugging this expression into equation A.17 would result in $\frac{d D}{d \gamma_{h}^{*}}<0$, which is a contradiction. If $\frac{d D}{d \gamma_{h}^{*}}<0$, it follows that $\frac{d E}{d \gamma_{h}^{*}}<0$. This implies that $\frac{d \max \left\{\gamma_{h}^{F}, \gamma_{h}^{B}\right\}}{d \gamma_{h}^{*}}<0$.

\section{Proof of Comparative Statics Results}

I derive comparative statics locally for the case where $\underline{\gamma}_{h}<\gamma_{h}^{A}<\gamma_{h}^{B}<\gamma_{h}^{*}$.

Proof of Proposition 4 To show $\frac{d \gamma_{h}^{B}}{d K_{f}}>0, \frac{d \gamma_{h}^{A}}{d K_{f}}>0$ and $\frac{d d_{f h}}{d K_{f}}>0$.

Note that $K_{f}$ only enters equation 20. Therefore, $\frac{d D}{d K_{f}}>0 . \quad D$ can only increase with an increase in $K_{f}$ if a bigger mass of home bankers borrow from depositors in the foreign country. This is only possible if the equilibrium difference between $\gamma_{f}^{*}$ and $\gamma_{h}^{*}$ is bigger. As a result, $\gamma_{h}^{B}$ and $\gamma_{h}^{A}$ must increase. More formally:

Suppose $\frac{d \gamma_{h}^{B}}{d K_{f}}<0$. This would imply that $\frac{d\left(\gamma_{f}^{*}-\gamma_{h}^{*}\right)}{d K_{f}}<0$ and hence, $\frac{d D}{d K_{f}}<0$. But if $\frac{d D}{d K_{f}}<0$, then, from equation $20, \frac{d \gamma_{h}^{A}}{d K_{f}}>0$, which is a contradiction.

Suppose $\frac{d \gamma_{h}^{A}}{d K_{f}}<0$. This would imply that $\frac{d\left(\gamma_{f}^{*}-\gamma_{h}^{*}\right)}{d K_{f}}<0$ and hence, $\frac{d D}{d K_{f}}<0$. But if $\frac{d D}{d K_{f}}<0$, then, from equation $20, \frac{d \gamma_{h}^{B}}{d K_{f}}>0$, which is a contradiction.

With a larger equilibrium gap in $\Delta \gamma^{*}=\gamma_{f}^{*}-\gamma_{h}^{*}$, the volume of borrowing $d_{f h}=$ $n\left(\gamma_{h}, R, \phi R_{f}^{D}\right)-1$ must go up.

Proof of Proposition 5 To show $\frac{d \gamma_{h}^{B}}{d \Delta}>0, \frac{d \gamma_{h}^{A}}{d \Delta}>0$ and $\frac{d d_{f h}}{d \Delta}>0$.

An increase in $\Delta$ increases $\gamma_{f}^{*}$ ceteris paribus. A higher $\gamma_{f}^{*}$ implies that $\gamma_{h}^{B}$ and $\gamma_{h}^{A}$ increase and thus the equilibrium gap $\Delta \gamma^{*}=\gamma_{f}^{*}-\gamma_{h}^{*}$ is higher. So the volume of borrowing $d_{12}=n\left(\gamma_{h}, R, \phi R_{f}^{D}\right)-1$ goes up. More formally:

Suppose $\frac{d \gamma_{h}^{B}}{d \Delta}<0$. This would imply that $\frac{d\left(\gamma_{f}^{*}-\gamma_{h}^{*}\right)}{d K_{f}}<0$ and hence, $\frac{d D}{d K_{f}}<0$. But if $\frac{d D}{d K_{f}}<0$, then from equation $20 \frac{d \gamma_{h}^{B}}{d \Delta}>0$, which is a contradiction.

Suppose $\frac{d \gamma_{h}^{A}}{d \Delta}<0$. This would imply that $\frac{d\left(\gamma_{f}^{*}-\gamma_{h}^{*}\right)}{d K_{f}}<0$ and hence, $\frac{d D}{d K_{f}}<0$. But if $\frac{d D}{d K_{f}}<0$, then from equation $20 \frac{d \gamma_{h}^{B}}{d \Delta}>0$, which is a contradiction.

With a larger equilibrium gap in $\Delta \gamma^{*}=\gamma_{f}^{*}-\gamma_{h}^{*}$, the volume of borrowing $d_{f h}=$ $n\left(\gamma_{h}, R, \phi R_{f}^{D}\right)-1$ must go up. 
Proof of Proposition 6 To show $\frac{d \gamma_{h}^{B}}{d \phi}<0$ and $\frac{d \gamma_{h}^{A}}{d \phi}>0$. Suppose $\frac{d \gamma_{h}^{B}}{d \phi}>0$. This would require $\frac{d\left(\gamma_{f}^{*}-\gamma_{h}^{*}\right)}{d \phi}>0$. But if $\frac{d\left(\gamma_{f}^{*}-\gamma_{h}^{*}\right)}{d \phi}>0$, from equation $21, \frac{d \gamma_{h}^{*}}{d \phi}>0$ and because $\frac{d \gamma_{h}^{A}}{d \phi}>0$, from equation $20, \frac{d \gamma_{f}^{*}}{d \phi}<0$, which contradicts $\frac{d\left(\gamma_{f}^{*}-\gamma_{h}^{*}\right)}{d \phi}>0$.

The proofs of the comparative statics with respect to $f^{A}$ and $f^{B}$ follow equivalently. 


\section{B General Model with $\tau=\phi=1$}

In this appendix, I characterize the solution to the general model. I discuss the different equilibrium cases that can occur for various parameter values and provide intuition for how the equilibrium case changes with key parameters of the model. To reduce the dimensionality, I assume that there are no variable costs to operating cross-border, i.e. $\tau=\phi=1$. This removes the decision of firms between operating from home or through FDI.

The following equilibrium cases can occur (corner solutions where all capitalists become depositors or bankers in one of the two countries are not considered): ${ }^{54}$

Proposition 7 Assume $\phi=\tau=1$. Then the following equilibrium cases are conceivable where $i, j \in\{1,2\}$ and $i \neq j$ :

(i) No trade.

(ii) Cross-border lending by banking sector $\mathbf{j}$ : Some banks from country $j$ invest domestic deposits in country $i . \gamma_{j}^{L}$ exists.

(iii) Cross-border lending and local intermediation by banking sector $\mathrm{j}$ : Some banks from country $j$ invest domestic deposits in country $i$; others raise foreign deposits and invest them in the foreign market. $\gamma_{j}^{L}$ and $\gamma_{j}^{B}$ both exist.

(iv) Local intermediation by banking sector $\mathbf{j}$ : Some banks from country $j$ raise foreign deposits and invest them in the foreign market. $\gamma_{j}^{B}$ exists and $R_{i}>R_{j}$.

(v) Local intermediation and cross-border borrowing by banking sector $\mathbf{j}$ : Some banks from country $j$ raise deposits in country $i$ and invest them at home and abroad. $\gamma_{j}^{B}$ exists and $R_{i}=R_{j}$.

(vi) Cross-border lending by banking sector $\mathrm{j}$ and cross-border borrowing by banking sector i: Some banks from country $j$ invest domestic deposits abroad, while some banks from country $i$ raise deposits in country $j$ and invest them at home. $\gamma_{j}^{L}$ and $\gamma_{i}^{B}$ both exist.

(vii) Cross-border borrowing by banking sector i: Some banks from country $i$ raise deposits in country $j$ and invest them at home. $\gamma_{i}^{B}$ exists and $R_{i}>R_{j}$.

\footnotetext{
${ }^{54}$ The word exist in the following means that the indifference condition that determines the respective cutoff has a solution and that this solution lies in the range of permissible values. For example, the cutoff $\gamma_{i}^{L}$ exists if it solves $\pi\left(\gamma_{j}\right)=\pi_{i j}^{X}\left(\gamma_{j}\right)$ and $\gamma_{i}^{L} \in\left\{\underline{\gamma}_{j}, \gamma_{j}^{*}\right\}$.
} 
Proof. Assume $A_{i}=A_{j}$ and $\Delta(K / L)=\frac{K_{j}}{L_{j}}-\frac{K_{i}}{L_{i}} \geq 0$ without loss of generality. (a) $\Delta(K / L) \geq 0$ implies that in equilibrium $R_{i} \geq R_{j}$. To see this note that if $R_{i}>R_{j}$ in autarky, it must be the case that $R_{i} \geq R_{i}$ in equilibrium. It is possible that banks source so much foreign capital from abroad for investment at home that rates of return to capital equalize in equilibrium. If $R_{i}=R_{j}$ in autarky, then in equilibrium $R_{i}=R_{j}$. This leaves the following combinations of equilibrium gross returns to capital and deposit rates possible:

(1) $R_{i}>R_{j} \& R_{i}^{D}<R_{j}^{D}$

(2) $R_{i}>R_{j} \& R_{i}^{D}>R_{j}^{D}$

(3) $R_{i}>R_{j} \& R_{i}^{D}=R_{j}^{D}$

(4) $R_{i}=R_{j} \& R_{i}^{D}<R_{j}^{D}$

(5) $R_{i}=R_{j} \& R_{i}^{D}>R_{j}^{D}$

(6) $R_{i}=R_{j} \& R_{i}^{D}=R_{j}^{D}$

(b) There are no upper limits on $f_{i j}^{L}, f_{j i}^{L}, f_{i j}^{B}$ and $f_{j i}^{B}$. So any of these fixed costs can be prohibitively high.

(c) In each country $j \in\{1,2\}$, there are four possibilities: $\gamma_{j}^{L}$ and $\gamma_{j}^{B}$ both do not exist, only $\gamma_{j}^{L}$ exists, only $\gamma_{j}^{B}$ exists, both $\gamma_{j}^{L}$ and $\gamma_{j}^{B}$ exist.

(d) Investing at home is costless in any case. Therefore if $R_{i}>R_{j}$, all banks in country $i$ must invest in country $i$.

(e) Capital must always flow in one direction, i.e. it cannot be the case that banks from country $j$ invest in country $i$ and banks from country $i$ invest in $j$.

(f) If $R_{i}=R_{j}$, no banker incurs the fixed cost of cross-border lending in equilibrium.

(g) It is not possible that banks in both countries raise deposits abroad in equilibrium. If $R_{i}^{D}>R_{j}^{D}$ only banks in country $i$ have incentives to invest in the fixed cost of FDI.

(h) If $R_{i}^{D}=R_{j}^{D}$, no banker incurs the fixed cost of cross-border borrowing in equilibrium.

Combining (a)-(h), we have that:

(1) If $R_{i}>R_{j} \& R_{i}^{D}<R_{j}^{D}, \gamma_{i}^{L}$ does not exist and $\gamma_{i}^{B}$ does not exist.

(2) If $R_{i}>R_{j} \& R_{i}^{D}>R_{j}^{D}, \gamma_{i}^{L}$ does not exist and $\gamma_{i}^{B}$ does not exist. Banks in country $i$ all invest in country $i$.

(3) If $R_{i}>R_{j} \& R_{i}^{D}=R_{j}^{D}, \gamma_{i}^{L}$ does not exist and $\gamma_{i}^{B}$ and $\gamma_{j}^{B}$ do not exist.

(4) If $R_{i}=R_{j} \& R_{i}^{D}>R_{j}^{D}, \gamma_{i}^{L}, \gamma_{j}^{L}$ and $\gamma_{j}^{B}$ do not exist. Banks in both countries are 
indifferent where to invest.

(5) If $R_{i}=R_{j} \& R_{i}^{D}<R_{j}^{D}, \gamma_{i}^{L}, \gamma_{j}^{L}$ and $\gamma_{i}^{B}$ do not exist. Banks in both countries are indifferent where to invest.

(6) If $R_{i}=R_{j} \& R_{i}^{D}=R_{j}^{D}, \gamma_{i}^{L}, \gamma_{j}^{L}, \gamma_{i}^{B}$ and $\gamma_{j}^{B}$ do not exist. The equilibrium corresponds to autarky.

Therefore, it can be that:

(A) There is no trade. Possible in all cases.

(B) Only $\gamma_{j}^{L}$ exists. Possible for cases (1) and (2).

(C) $\gamma_{j}^{L}$ and $\gamma_{j}^{B}$ both exist: Possible for case (1).

(D) $\gamma_{j}^{L}$ and $\gamma_{i}^{B}$ both exist: Possible for case (2).

(E) $\gamma_{j}^{B}$ exists: Possible for case (1) and (5).

(F) $\gamma_{i}^{B}$ exists: Possible for case (2) and (4).

Now distinguish (E) and (F) again by the equilibrium values that $R_{i}$ and $R_{j}$ take:

(E1) $\gamma_{j}^{B}$ exists and (1): banks that pay $f_{i j}^{B}$ invest in country $i$.

(E2) $\gamma_{j}^{B}$ exists and (5): banks in country $j$ invest at home and abroad.

(F1) $\gamma_{i}^{B}$ exists and (2): banks that pay $f_{j i}^{B}$ invest in country $i$.

(F2) $\gamma_{i}^{B}$ exists and (4): banks in country $i$ invest at home and abroad.

Then, we obtain the eight cases as stated in the proposition.

Figure B.1, which is obtained from simulating the model numerically, illustrates the different equilibrium cases. It shows how the equilibrium changes with the capital-labor ratio of country $1 K_{1} / L_{1}$ and with the support of the monitoring cost distribution of country 1, i.e. with changes in $\underline{\gamma}_{1}$ keeping the characteristics of country 2 fixed. As the size of the capital stock affects the realized monitoring cost distribution, the capital-labor ratio of country 1 is varied by modifying the labor endowment instead of the capital endowment and $A_{1}=A_{2}$.

Consider figure B.1 and focus on the case where country 1 is relatively capital scarce. Start from a situation where country 1 has a very efficient banking sector relative to country 2 , i.e. begin in the right lower corner of the graph. Under the assumed parameters, equilibrium case (vii) prevails, that is, banking sector 1 borrows capital from depositors in country 2 
for investment at home, hence importing capital from country 2. Banking sector 2 operates only at home.

Figure B.1: Equilibrium types as a function of $K_{1} / L_{1}$ and $\underline{\gamma}_{1}$

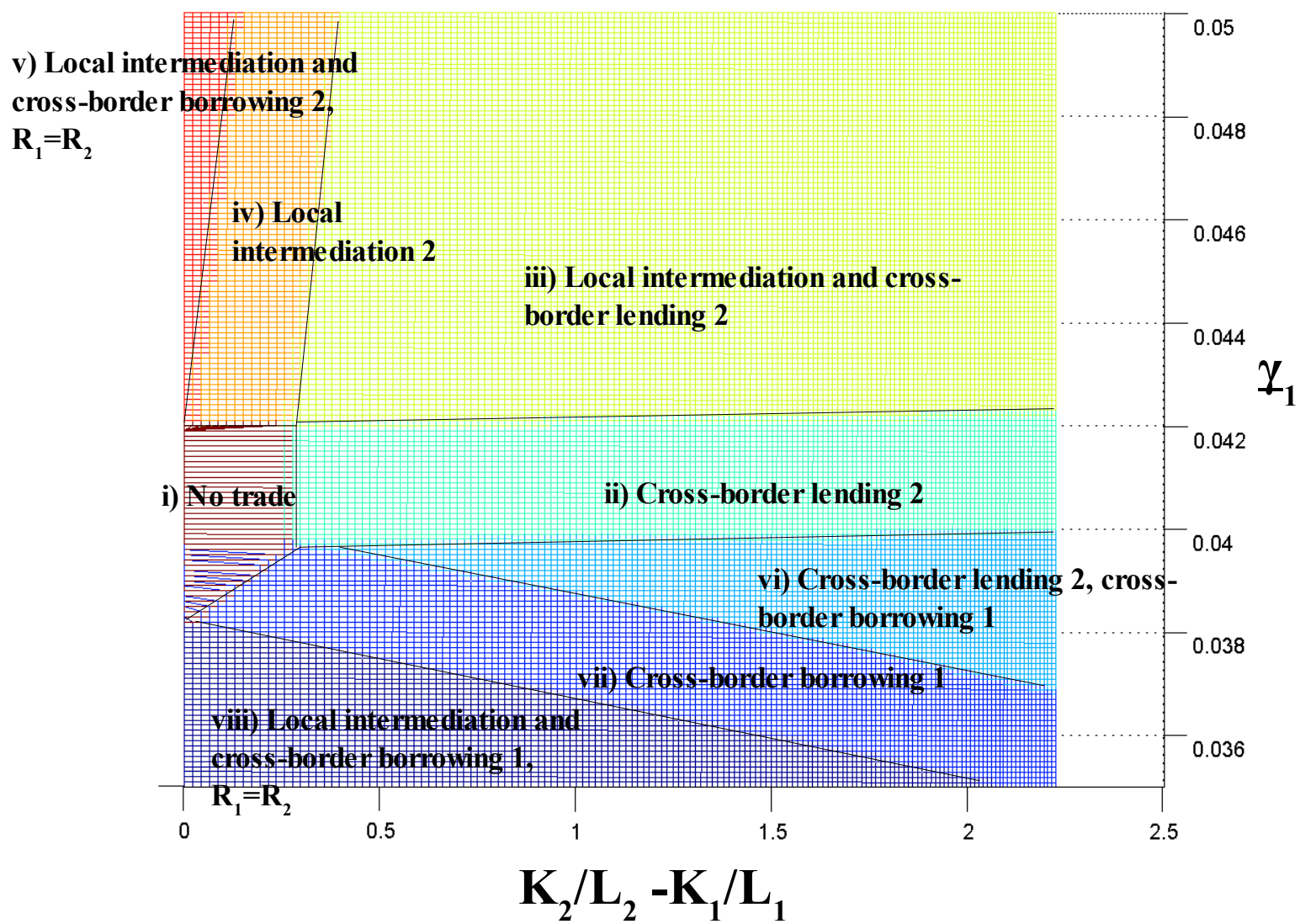

The graph is obtained from simulating the model for the following parameter values: Cobb-Douglas production function with a labor share of $0.3, \lambda^{L}=0.5, \lambda=0.985, f^{L}=$ $0.13, f^{B}=0.16$, uniform distribution, $\underline{\gamma}_{2}=0.04$ and $\bar{\gamma}_{1}=\bar{\gamma}_{2}=0.4, K_{2} / L_{2}=20 / 3$, $A_{1}=A_{2}, K_{1} / L_{1} \in[20 / 3,20 / 4.5], \underline{\gamma}_{1} \in[0.035,0.05]$.

Next move upward along the $y$-axis. As $\underline{\gamma}_{1}$ increases and banking sector 1 becomes less efficient, banks in country 2 start to engage in cross-border lending simultaneously (case (vi)). Because the interest rate in country 1 decreases and because banks in country 1 become less efficient, fewer banks in country 1 borrow from depositors abroad. This implies that the spread in gross returns to capital grows larger ceteris paribus, which makes it attractive for banks in country 2 to invest abroad.

As the efficiency of banking sector 1 decreases even more, banks in country 1 are, at some 
point, not efficient enough and differences in deposit rates are not large enough to make any bank in country 1 incur the fixed cost of cross-border borrowing. In this case, only banking sector 2 is active across borders and lends to firms in country 1 (case (ii)).

With a further decline in $\underline{\gamma_{1}}$, the deposit rate in country 1 can decrease to the point where it is profitable for banks in country 2 not only to lend to firms in country 1 but also to borrow from depositors in country 1. Then, banking sector 2 engages in both cross-border lending and borrowing in equilibrium, exporting capital on net (case (iii)).

Next, consider how the equilibrium varies along the $x$-axis, that is, with changes in $K_{1} / L_{1}$. Start where countries have equal capital endowments so that there is no reason why capital should flow across borders. If differences in efficiencies are also small $\left(\gamma_{i} \approx 0.04\right)$, there is no trade in banking services at all. The equilibrium corresponds to autarky. If, however, one banking sector is sufficiently more efficient than the other, that banking sector expands by intermediating foreign deposits locally. With equal gross returns to capital in the two countries, banks incur the fixed cost of cross-border borrowing and invest at home and abroad to keep returns equated. This is the case discussed in section 4 . Which banks lend to firms at home and abroad, is not determined in this case. Because gross returns to capital are equal, all banks that pay the fixed cost are indifferent between investing at home and abroad.

Now let country 1 become capital scarce, that is, move to the right along the $x$-axis. As the capital-labor ratio of country 1 declines, additional banks become internationally active. Whether these are banks in country 1 or in country 2 depends on which banking sector is more efficient. In a nutshell: differences in capital-labor ratios determine the direction of the cross-border capital flow. Differences in banking sector efficiencies fix which banks channel capital across borders. This intuition is similar to the model with homogenous banks in Niepmann (2015). 


\section{Data Appendix}

External Position of Banks (AUSTA - "Auslandsstatus der Banken"): Total crossborders assets and liabilities of bank $k$ in country $i$ are measured as the cross-border assets and liabilities of parent bank $k$ minus the liabilities of its affiliates located in country $i$ visa-vis the parent. Local assets (liabilities) comprise the assets (liabilities) of all affiliates of bank $k$ located in country $i$ towards residents of country $i$. Branches and subsidiaries are matched to the parent as of June 2005. Data come at a monthly frequency and are averaged over 12 months. See Fiorentino et al. (2010) for a detailed description of the data source.

Monthly Balance Sheet Statistics (BISTA - "Monatliche Bilanzstatistik") and Income and Loss Data (GuV - "Gewinn und Verlustrechnung der Banken"): Information on balance sheet size, bank equity, overhead costs and the number of employees are from Monthly balance sheet statistics and Income and loss data available at the Deutsche Bundesbank. Values represent yearly averages for the parent bank plus its domestic and foreign branches.

Data on marginal products of capital (MPK): David et al. (2014) kindly provided information on capital stocks and MPKs by country. The MPKs used in this paper are based on the method suggested by Caselli and Feyrer (2007) and were calculated using country specific prices of output, consumption and investment. I complement the dataset with information on the labor force. I then assume a Cobb-Douglas production function $Y=A K^{\alpha} L^{1-\alpha}$ with a capital share of $\alpha=0.3$ consistent with David et al. (2014) to back out $A$ for the simulation and normalize the Czech Republic's capital stock by the German capital stock. The regressions include MPK values for the year 2000.

Additional variables: GDP in current \$US and GDP per capita in current \$US are obtained from the World Development Indicators. Data on average overhead costs to total assets of a country are from the World Bank's Financial Development and Structure Dataset (see Beck et al. (2009)). Distance to Germany comes from a dataset provided by CEPII (see Mayer and Zignago (2005)). The Financial Freedom Index is from the Heritage Foundation. Bureaucratic quality is from the International Country Risk Guide provided by the PRS Group. 


\section{References}

Adrian, Tobias and Hyun Song Shin, "Procyclical Leverage and Value-at-Risk," Review of Financial Studies, 2014, 27 (2), 373-403.

Allen, Franklin, Thorsten Beck, Elena Carletti, Philip R. Lane, Dirk Schoenmaker, and Wolf Wagner, "Cross-Border Banking in Europe: Implications for Financial Stability and Macroeconomic Policy," Technical Report, Center for Economic Policy Research June 2011.

Antras, Pol and Ricardo J. Caballero, "Trade and Capital Flows: A Financial Frictions Perspective," Journal of Political Economy, 08 2009, 117 (4), 701-744.

Beck, Thorsten, Asli Demirguc-Kunt, and Ross Levine, "Bank concentration, competition, and crises: First results," Journal of Banking $E$ Finance, May 2006, 30 (5), $1581-1603$.

_, Asli Demirgüç-Kunt, and Ross Levine, "Financial institutions and markets across countries and over time - data and analysis," Policy Research Working Paper Series 4943, The World Bank May 2009.

Berger, Allen N. and Loretta J. Mester, "Inside the black box: What explains differences in the efficiencies of financial institutions?," Journal of Banking ES Finance, 1997, $21(7), 895-947$.

Bernard, Andrew B., J. Bradford Jensen, Stephen J. Redding, and Peter K. Schott, "The Empirics of Firm Heterogeneity and International Trade," Annual Review of Economics, 2012, 4 (1), null.

_, Jonathan Eaton, J. Bradford Jensen, and Samuel Kortum, "Plants and Productivity in International Trade," American Economic Review, September 2003, 93 (4), $1268-1290$.

Blas, Beatriz De and Katheryn Russ, "FDI in the Banking Sector," NBER Working Papers 16029, National Bureau of Economic Research 2010. 
_ and _ , "All banks great, small, and global: Loan pricing and foreign competition," International Review of Economics and Finance, 2012. Forthcoming.

Brevoort, Kenneth $\mathbf{P}$ and John D Wolken, "Does distance matter in banking?," The Changing Geography of Banking and Finance, 2009, pp. 27-56.

Buch, Claudia M., "Information or Regulation: What Drives the International Activities of Commercial Banks," Journal of Money Credit and Banking, 2003, 35 (6), 851-869.

_. , "Distance and International Banking," Review of International Economics, 2005, 13 (4), 787-804.

_ , Catherine Tahmee Koch, and Michael Koetter, "Size, productivity and international banking," Journal of International Economics, 2011, 85 (2), 329-334.

_ , _ and _ , "Should I stay or should I go? Bank productivity and internationalization decisions," Journal of Banking \&3 Finance, 2014, 42, 266 - 282.

Caselli, Francesco and James Feyrer, "The Marginal Product of Capital," The Quarterly Journal of Economics, 2007, 122 (2), 535-568.

Committee on the Global Financial System, "Long-term issues in international banking," CGFS Paper 41, Bank for International Settlements July 2010.

Corbae, Dean and Pablo D’Erasmo, "A Quantitative Model of Banking Industry Dynamics," 2010 Meeting Papers 268, Society for Economic Dynamics 2010.

_ and _, "Foreign Competition and Banking Industry Dynamics: An Application to Mexico," IMF Economic Review. Forthcoming.

David, Joel M., Espen Henriksen, and Ina Simonovska, "The Risky Capital of Emerging Markets," NBER Working Papers 20769, National Bureau of Economic Research, Inc December 2014.

Degryse, Hans and Steven Ongena, "Distance, Lending Relationships, and Competition," The Journal of Finance, 2005, 60 (1), 231-266. 
Detragiache, Enrica, Abdul Abiad, and Thierry Tressel, "A New Database of Financial Reforms," IMF Working Papers 08/266, International Monetary Fund 2008.

Ennis, Huberto M., "On the size distribution of banks," Economic Quarterly, 2001, Fall, 1-25.

Fillat, José L, Stefania Garetto, and Martin Götz, "Multinational Banks," Technical Report 2015. Mimeo.

Fiorentino, Elisabetta, Catherine Koch, and Winfried Rudek, "External Position Reports of German Banks - A Description of the Microdatabase," Technical Documentation, Deutsche Bundesbank 2010.

Focarelli, Dario and Alberto F. Pozzolo, "Where Do Banks Expand Abroad? An Empirical Analysis," Journal of Business, November 2005, 78 (6), 2435-2464.

Francois, Joseph and Bernard Hoekman, "Services Trade and Policy," Journal of Economic Literature, 2010, 48 (3), 642-92.

Helpman, Elhanan, Marc J. Melitz, and Stephen R. Yeaple, "Export Versus FDI with Heterogeneous Firms," American Economic Review, 2004, 94 (1), 300-316.

Holmstrom, Bengt and Jean Tirole, "Financial Intermediation, Loanable Funds, and the Real Sector," The Quarterly Journal of Economics, August 1997, 112 (3), 663-91.

Hughes, Joseph P. and Loretta J. Mester, "Efficiency in banking: theory, practice, and evidence," Technical Report 2008.

Janicki, Hubert P. and Edward Simpson Prescott, "Changes in the size distribution of U.S. banks: 1960-2005," Economic Quarterly, 2006, (Fall), 291-316.

Ju, Jiandong and Shang-Jin Wei, "Domestic Institutions and the Bypass Effect of Financial Globalization," American Economic Journal: Economic Policy, 2010, 2 (4), $173-204$.

Kalemli-Ozcan, Sebnem, Bent Sorensen, and Sevcan Yesiltas, "Leverage across firms, banks, and countries," Journal of International Economics, 2012, 88 (2), 284 - 298. 
Kerl, Cornelia and Friederike Niepmann, "What determines the composition of international bank flows?," IMF Economic Review. Forthcoming.

Lehner, Maria, "Entry mode choice of multinational banks," Journal of Banking and Finance, 2009, 33, 1781-1792.

Mayer, Thierry and Soledad Zignago, "Market Access in Global and Regional Trade," Working Papers 2005-02, CEPII research center January 2005.

McCord, Roisin, Edward Simpson Prescott et al., "The Financial Crisis, the Collapse of Bank Entry, and Changes in the Size Distribution of Banks," Economic Quarterly, 2014, (1Q), 23-50.

Melitz, Marc J., "The Impact of Trade on Intra-Industry Reallocations and Aggregate Industry Productivity," Econometrica, November 2003, 71 (6), 1695-1725.

Mrazova, Monika and J. Peter Neary, "Selection effects with heterogeneous firms," Economics Series Working Papers 588, University of Oxford, Department of Economics 2011.

Niepmann, Friederike, "Banking across borders with heterogeneous banks," FRB of New York Staff Report, 2013, (609).

_ , "Banking across borders," Journal of International Economics, 2015, 96 (2), 244 - 265.

Papaioannou, Elias, "What drives international financial flows? Politics, institutions and other determinants," Journal of Development Economics, March 2009, 88 (2), 269-281.

Yeaple, Stephen R., "Firm heterogeneity and the structure of U.S. multinational activity," Journal of International Economics, July 2009, 78 (2), 206-215. 


\section{Tables}

Table 1: Parameters used to simulate the model

\begin{tabular}{lc}
\hline Exogeneous parameters & Values \\
\hline Size of capital input per firm z & 1 \\
Capital share $\alpha$ in Cobb-Douglas production function & 0.3 \\
Shape parameter of Pareto distribution & 0.55 \\
Lower bound of Pareto distribution GER $\underline{\gamma_{G}}$ & 0.006317 \\
Lower bound of Pareto distribution CZE $\underline{\gamma_{C}}$ & 0.010344 \\
Capital endowment GER $K_{G}$ & 1 \\
Labor endowment GER $L_{G}$ & 5.61 \\
TFP GER $A_{G}$ & 0.064524 \\
Capital endowment CZE $K_{C}$ & 0.08145 \\
Capital endowment CZE $L_{C}$ & 0.72206 \\
TFP CZE $A_{C}$ & 0.046366 \\
Success probability without monitoring $\lambda_{L}$ & 0.85 \\
Success probability with monitoring $\lambda$ & 0.9 \\
Variable cost of borrowing abroad $\phi$ & 1.001 \\
Fixed cost of borrowing abroad $f^{B}$ & 0.24 \\
\hline
\end{tabular}

The table summarizes the parameter values that are used to simulate the model. See section 4.2 for details. 


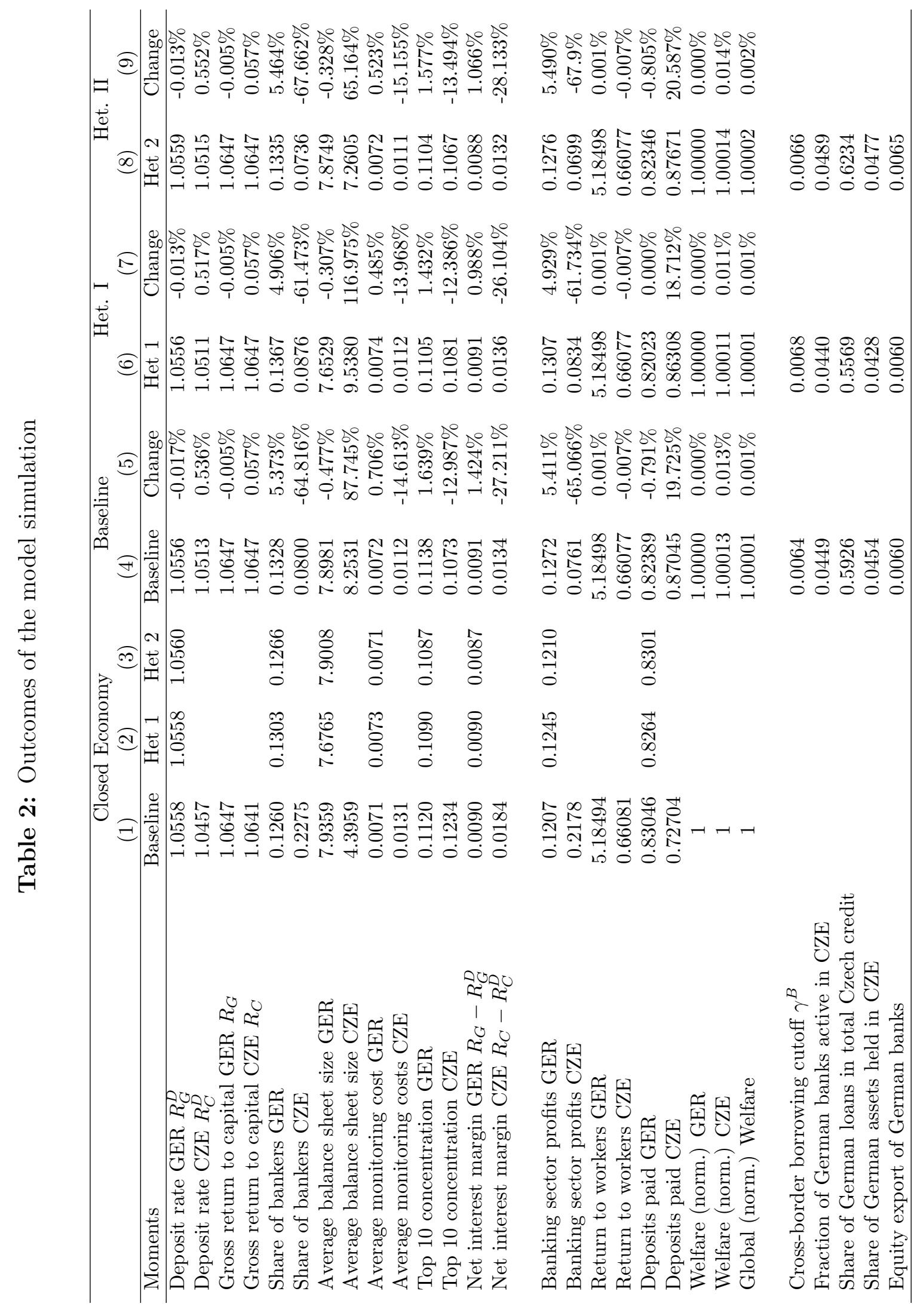

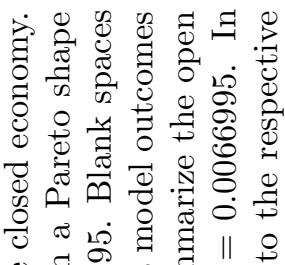

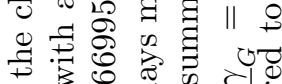
$\exists$ : कै दे ०: 氶 तี \%

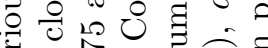
范 पै

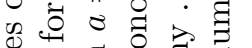
สิ ప

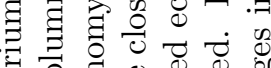
范 : $\exists$ के च ज O

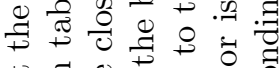

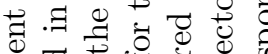
के च्र

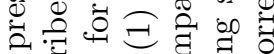
๙ิ ○

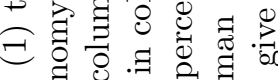
范 㱐

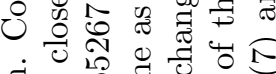

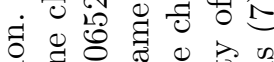

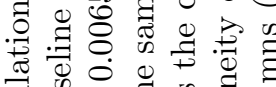

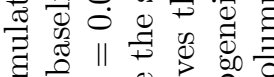

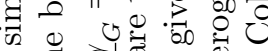

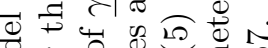
웅. क द व द्व 0 है 幽寻

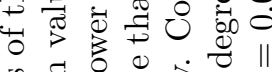
छ

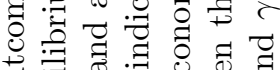
쿠유

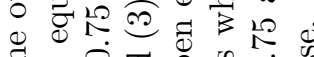

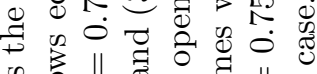

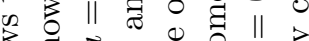

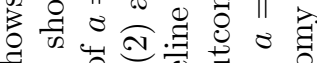
ज记

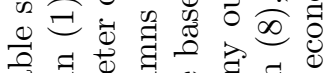
ॠ 芩

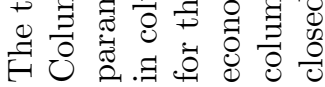


Table 3: Relationship between bank size, leverage and efficiency

\begin{tabular}{lcc}
\hline & \multicolumn{2}{c}{$\log (\text { size })_{k}$} \\
& $1.003^{* * *}$ & $1.012^{* * *}$ \\
$\log \left(\right.$ equity $\left._{k}\right)$ & $(0.00898)$ & $(0.00781)$ \\
$\log \left({\left.\text { overhead } \operatorname{costs}_{k}\right)}^{-0.287^{* * *}}\right.$ & \\
& $(0.0477)$ & \\
$\log \left(\right.$ labor prod $\left._{k}\right)$ & & $0.194^{* * *}$ \\
& & $(0.0350)$ \\
Constant & $10.68^{* * *}$ & $8.127^{* * *}$ \\
& $(0.173)$ & $(0.276)$ \\
& & \\
Observations & 1,909 & 1,909 \\
$R^{2}$ & 0.960 & 0.957 \\
\hline
\end{tabular}

The table presents results from regressing the log balance sheet size of bank $k$ on its log equity and its efficiency. In column (1), a bank's ratio of overhead costs to total assets is used as an inverse measure of efficiency. Column (2) includes the bank's number of assets per employee instead. The sample comprises 1,909 German banks in 2005. Robust standard errors are in parentheses. *** $\mathrm{p}<0.01,{ }^{* *} \mathrm{p}<0.05,{ }^{*} \mathrm{p}<0.1$. Data source: Research Data and Service Centre of the Deutsche Bundesbank, External Position of Banks, Monthly Balance Sheet Statistics and Income and Loss Data.

Table 4: Effect of size and efficiency on the extensive and intensive margins

\begin{tabular}{lccccccc}
\hline & \multicolumn{3}{c}{ Extensive Margin: Logit Model } & \multicolumn{4}{c}{ Intensive Margin: OLS } \\
& $\begin{array}{c}\text { cr. ass } \\
(1)\end{array}$ & $\begin{array}{c}\text { cr. liab }{ }_{k i} \\
(2)\end{array}$ & $\begin{array}{c}\mathrm{FDI}_{k i} \\
(3)\end{array}$ & $\begin{array}{c}\text { cr. ass }_{k i} \\
(4)\end{array}$ & $\begin{array}{c}\text { local ass } \\
(5)\end{array}$ & $\begin{array}{c}\text { cr. liab } \\
(6)\end{array}$ & $\begin{array}{c}\text { local liab } \\
(7)\end{array}$ \\
\hline $\log \left(\right.$ overhead $\left._{k}\right)$ & $-0.807^{* * *}$ & $-0.850^{* * *}$ & $-0.922^{* * *}$ & $-1.682^{* * *}$ & -0.386 & $-1.347^{* * *}$ & 0.00515 \\
& $(0.135)$ & $(0.126)$ & $(0.253)$ & $(0.232)$ & $(0.390)$ & $(0.232)$ & $(0.889)$ \\
& & & & & & & \\
Observations & 337,705 & 339,624 & 110,606 & 35758 & 251 & 59259 & 241 \\
$\left(\right.$ Pseudo) $R^{2}$ & 0.483 & 0.375 & 0.458 & 0.408 & 0.571 & 0.271 & 0.476 \\
\hline
\end{tabular}

The table shows that the extensive and intensive margins of banking across borders vary systematically with bank efficiency. Columns (1) to (3) show the results of logit regressions. Columns (4) to (7) are obtained from OLS regressions. In each regression, the dependent variable is regressed on bank $k$ 's ratio of overhead costs to total assets, which measures inversely the bank's efficiency. The dependent variable takes a value of 1 if bank $k$ has cross-border assets (column 1), cross-border liabilities (column 2) or affiliates (column 3) in country $i$. In columns (4) and (6), the dependent variable reflects the cross-border assets and liabilities in country $i$ on the balance sheet of the parent bank, respectively, in logs. In columns (5) and (7), the local positions, that is, the assets and liabilities of the parent's foreign affiliates in country $i$, are used as right-hand side variables, also in logs. Regressions include country-fixed effects and dummies for one of nine bank types. Standard errors clustered by bank are in parentheses. ${ }^{* * *} \mathrm{p}<0.01,{ }^{* *} \mathrm{p}<0.05,{ }^{*} \mathrm{p}<0.1$. Data source: Research Data and Service Centre of the Deutsche Bundesbank, External Position of Banks, Monthly Balance Sheet Statistics and Income and Loss Data. 
Table 5: Predicted relationship between extensive/intensive margins and host country characteristics

\begin{tabular}{lccc}
\hline & \multicolumn{2}{c}{ extensive margin } & intensive margin \\
& cb cutoff $\gamma_{i}^{B}$ & FDI cutoff $\gamma_{i}^{A}$ & for. liabilities \\
\hline host country intermediation costs $\Delta_{i}$ & + & + & + \\
host country size $K_{i}$ & + & + & + \\
$\phi_{i}$ & - & + & \\
$f_{i}^{B}$ & - & + & \\
$f_{i}^{F}$ & + & - & \\
\hline
\end{tabular}

The table summarizes the predictions of the model stated in propositions 4,5 and 6 regarding the behaviour of the extensive and intensive margins of banking across borders with respect to host country $i$ characteristics. 
Table 6: Relationship between extensive margin and host country characteristics

\begin{tabular}{|c|c|c|c|}
\hline & \multicolumn{3}{|c|}{ Extensive Margin: Logit Model } \\
\hline & $\begin{array}{l}\text { cr. } \operatorname{assets}_{k i} \\
\text { (1) }\end{array}$ & $\begin{array}{c}\text { cr. liabilities } \\
(2)\end{array}$ & $\begin{array}{c}\mathrm{FDI}_{k i} \\
(3)\end{array}$ \\
\hline $\log \left(\right.$ overhead $\left.\operatorname{costs}_{i}\right)$ & $\begin{array}{c}0.473^{* *} \\
(0.203)\end{array}$ & $\begin{array}{c}0.380^{* *} \\
(0.193)\end{array}$ & $\begin{array}{l}-0.208 \\
(0.400)\end{array}$ \\
\hline $\log (\text { distance })_{i}$ & $\begin{array}{c}-0.483^{* * *} \\
(0.137)\end{array}$ & $\begin{array}{c}-0.444^{* * *} \\
(0.127)\end{array}$ & $\begin{array}{c}-0.781^{* * *} \\
(0.161)\end{array}$ \\
\hline fin. freedom ${ }_{i}$ & $\begin{array}{c}0.0191^{*} \\
(0.00977)\end{array}$ & $\begin{array}{c}0.0181^{* * *} \\
(0.00587)\end{array}$ & $\begin{array}{l}0.0187^{* *} \\
(0.00912)\end{array}$ \\
\hline bureaucr. quality $i$ & $\begin{array}{l}0.551^{* *} \\
(0.227)\end{array}$ & $\begin{array}{c}0.200 \\
(0.172)\end{array}$ & $\begin{array}{c}-0.0521 \\
(0.304)\end{array}$ \\
\hline $\log (\mathrm{GDP})_{i}$ & $\begin{array}{c}0.739^{* * *} \\
(0.0793)\end{array}$ & $\begin{array}{c}0.844^{* * *} \\
(0.0598)\end{array}$ & $\begin{array}{c}0.954^{* * *} * \\
(0.148)\end{array}$ \\
\hline $\log (\text { GDP per cap. })_{i}$ & $\begin{array}{c}0.244 \\
(0.169)\end{array}$ & $\begin{array}{c}-0.0254 \\
(0.119)\end{array}$ & $\begin{array}{l}-0.164 \\
(0.204)\end{array}$ \\
\hline $\mathrm{MPK}_{i}$ & $\begin{array}{l}2.766^{* *} \\
(1.288)\end{array}$ & $\begin{array}{c}0.687 \\
(0.940)\end{array}$ & $\begin{array}{l}-1.005 \\
(2.584)\end{array}$ \\
\hline Observations & 177,563 & 176,940 & 3,600 \\
\hline Pseudo $R^{2}$ & 0.5046 & 0.4511 & 0.4879 \\
\hline
\end{tabular}

The table shows results from logit regressions. The dependent variable takes a value of 1 if bank $k$ has cross-border assets (column 1), cross-border liabilities (column 2) or affiliates (column 3) in country $i$. The respective dependent variable is regressed on various country $i$ characteristics described in detail in section 6.5. Regressions include bank-fixed effects. Standard errors clustered by country are in parentheses. ${ }^{* * *} \mathrm{p}<0.01,{ }^{* *} \mathrm{p}<0.05,{ }^{*} \mathrm{p}<0.1$. Data source: Research Data and Service Centre of the Deutsche Bundesbank, External Position of Banks. For details on country-level variables, see the data appendix. 
Table 7: Cutoff regressions

\begin{tabular}{|c|c|c|c|c|c|c|}
\hline & \multicolumn{2}{|c|}{ cr. assets } & \multicolumn{2}{|c|}{ cr. liabilities } & \multicolumn{2}{|c|}{ FDI } \\
\hline & $\operatorname{max.}_{\text {(1) }} \operatorname{ov}_{i}$ & $\begin{array}{c}\text { average } \text { ov }_{i} \\
\text { (2) }\end{array}$ & $\begin{array}{c}\max . \mathrm{ov}_{i} \\
(3)\end{array}$ & $\begin{array}{c}\text { average ov } i \\
\text { (4) }\end{array}$ & $\max _{(5)} \mathrm{ov}_{i}$ & $\begin{array}{c}\text { average } \text { ov }_{i} \\
\text { (6) }\end{array}$ \\
\hline $\log \left(\right.$ overhead $\left.\operatorname{costs}_{i}\right)$ & $0.189^{*}$ & $0.0388^{* *}$ & $0.324^{* * *}$ & $0.0243^{* * *}$ & 0.0398 & 0.0695 \\
\hline & $(0.0970)$ & $(0.0165)$ & $(0.0794)$ & $(0.00678)$ & $(0.0975)$ & $(0.0783)$ \\
\hline $\log (\text { distance })_{i}$ & $\begin{array}{c}-0.229 * * * \\
(0.0642)\end{array}$ & $\begin{array}{c}-0.0349^{* * *} * \\
(0.00944)\end{array}$ & $\begin{array}{c}-0.0949^{*} \\
(0.0493)\end{array}$ & $\begin{array}{c}-0.0117 * * * \\
(0.00402)\end{array}$ & $\begin{array}{c}-0.248^{* * *} \\
(0.0451)\end{array}$ & $\begin{array}{c}-0.0679^{*} \\
(0.0386)\end{array}$ \\
\hline fin. freedom ${ }_{i}$ & $\begin{array}{c}0.00624^{* *} \\
(0.00239)\end{array}$ & $\begin{array}{l}0.00133^{* *} \\
(0.000543)\end{array}$ & $\begin{array}{l}0.00424^{*} \\
(0.00244)\end{array}$ & $\begin{array}{c}0.000756^{* * *} \\
(0.000234)\end{array}$ & $\begin{array}{l}-4.50 \mathrm{e}-05 \\
(0.00321)\end{array}$ & $\begin{array}{l}-0.00165 \\
(0.00318)\end{array}$ \\
\hline bureaucr. quality $_{i}$ & $\begin{array}{c}0.182^{* *} \\
(0.0696)\end{array}$ & $\begin{array}{c}0.0560^{* * *} \\
(0.0162)\end{array}$ & $\begin{array}{c}0.260^{* * *} \\
(0.0661)\end{array}$ & $\begin{array}{l}0.0141^{* *} \\
(0.00605)\end{array}$ & $\begin{array}{l}-0.0310 \\
(0.0921)\end{array}$ & $\begin{array}{c}0.0349 \\
(0.0751)\end{array}$ \\
\hline $\log (\mathrm{GDP})_{i}$ & $\begin{array}{c}0.189^{* * *} \\
(0.0406)\end{array}$ & $\begin{array}{c}0.0322^{* * *} \\
(0.00802)\end{array}$ & $\begin{array}{c}0.257^{* * *} \\
(0.0306)\end{array}$ & $\begin{array}{c}0.0260^{* * * *} \\
(0.00265)\end{array}$ & $\begin{array}{r}-0.00834 \\
(0.0312)\end{array}$ & $\begin{array}{l}-0.0448 \\
(0.0292)\end{array}$ \\
\hline $\log (\text { GDP per cap. })_{i}$ & $\begin{array}{c}-0.0489 \\
(0.0408)\end{array}$ & $\begin{array}{c}-0.0306^{* *} \\
(0.0118)\end{array}$ & $\begin{array}{c}-0.0981^{* *} \\
(0.0449)\end{array}$ & $\begin{array}{l}-0.00413 \\
(0.00540)\end{array}$ & $\begin{array}{c}0.0617 \\
(0.0578)\end{array}$ & $\begin{array}{l}-0.0766 \\
(0.0550)\end{array}$ \\
\hline $\mathrm{MPK}_{i}$ & $\begin{array}{l}-0.101 \\
(0.503)\end{array}$ & $\begin{array}{l}-0.115 \\
(0.114)\end{array}$ & $\begin{array}{l}-0.694 \\
(0.508)\end{array}$ & $\begin{array}{l}-0.0386 \\
(0.0440)\end{array}$ & $\begin{array}{l}-0.217 \\
(1.514)\end{array}$ & $\begin{array}{c}0.218 \\
(1.056)\end{array}$ \\
\hline Constant & $\begin{array}{l}1.900^{*} \\
(1.103)\end{array}$ & $\begin{array}{c}2.679^{* * *} \\
(0.186)\end{array}$ & $\begin{array}{l}0.0372 \\
(0.867)\end{array}$ & $\begin{array}{c}2.577^{* * *} \\
(0.0817)\end{array}$ & $\begin{array}{c}4.870^{* * *} \\
(0.910)\end{array}$ & $\begin{array}{c}5.164^{* * * *} \\
(0.873)\end{array}$ \\
\hline Observations & 96 & 96 & 97 & 97 & 38 & 38 \\
\hline R-squared & 0.623 & 0.512 & 0.647 & 0.724 & 0.629 & 0.247 \\
\hline
\end{tabular}

The table demonstrate that there is strong sorting of banks into foreign activities based on host country characteristics. In column 1, the dependent variable corresponds to the ratio of overhead costs to total assets of the least efficient bank that has cross-border assets in country $i$. Accordingly, there is one observation per country in the underlying sample. In column 2, the dependent variable represents the average ratio of overhead costs to total assets of all banks that have cross-border assets in country $i$. In columns (3) and (4), maximum and average overhead costs are determined based on banks' foreign liabilities. In columns (5) and (6), maximum and minimum overhead costs are taken over those banks that have one or more affiliates in country $i$. In each column, the respective dependent variable is regressed on host country $i$ characteristics. Robust standard errors are in parentheses. ${ }^{* * *} \mathrm{p}<0.01,{ }^{* *} \mathrm{p}<0.05,{ }^{*} \mathrm{p}<0.1$. Data source: Research Data and Service Centre of the Deutsche Bundesbank, External Position of Banks, Monthly Balance Sheet Statistics and Income and Loss Data. For details on country-level variables, see the data appendix. 


\section{Figures}

Figure 1: Sorting of banks into cross-border lending, cross-border borrowing and FDI

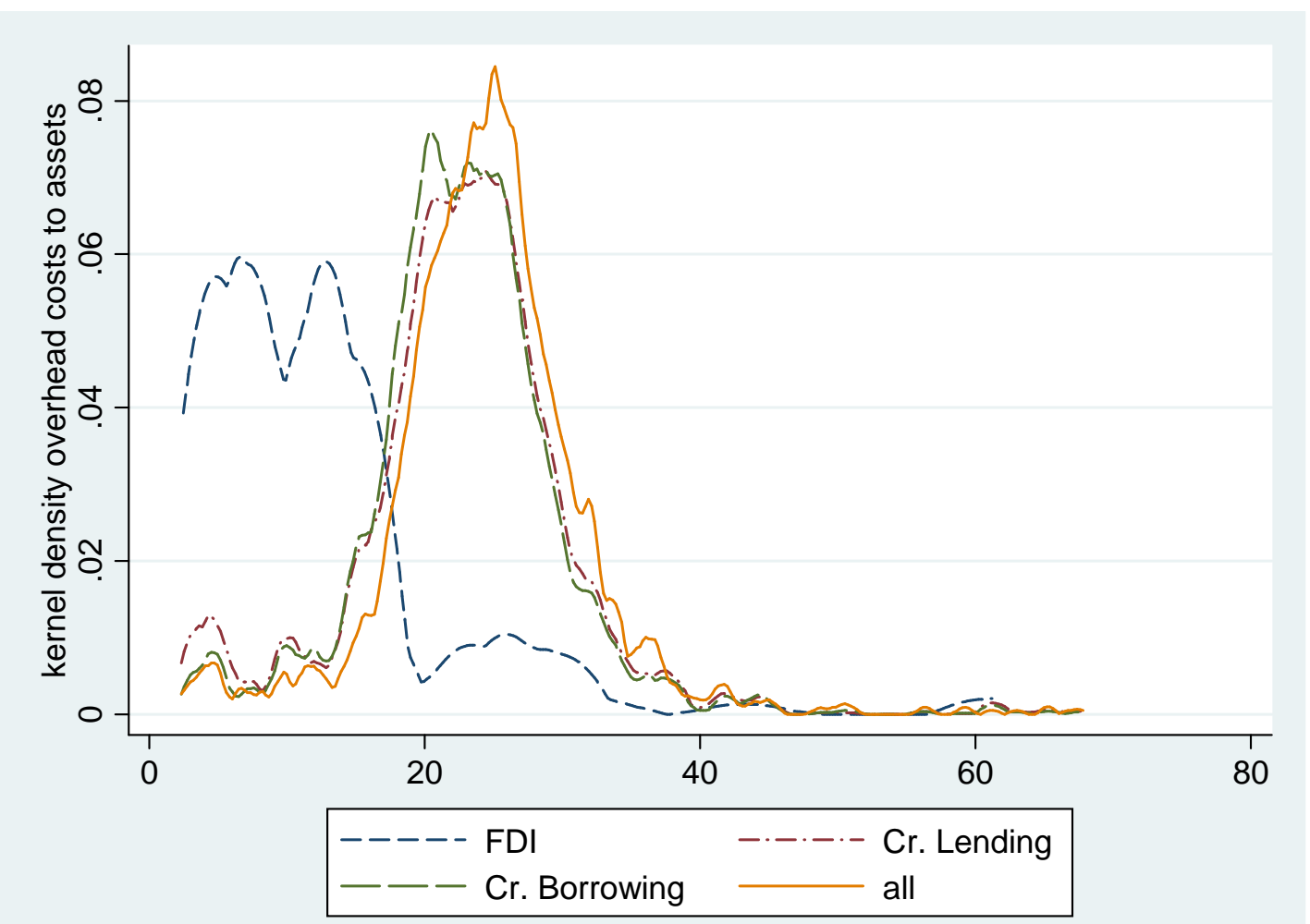

The figure illustrates that banks sort into foreign activities based on their efficiency proxied by a bank's ratio of overhead costs to total assets. Specifically, the chart plots the overhead costs distribution of different groups of German banks in 2005. The solid line shows the distribution for all banks in the bank-level dataset from the Deutsche Bundesbank. The dash-dotted line depicts the overhead cost distribution of banks with cross-border assets in country $i$. The line with long (short) dashes represents the size distribution of banks with cross-border liabilities (affiliates) in country $i$. Source: Research Data and Service Centre of the Deutsche Bundesbank, External Position of Banks, Monthly Balance Sheet Statistics and Income and Loss data, 2005, own calculations. 
Figure 2: Bank size as a function of monitoring costs in autarky and in the open economy
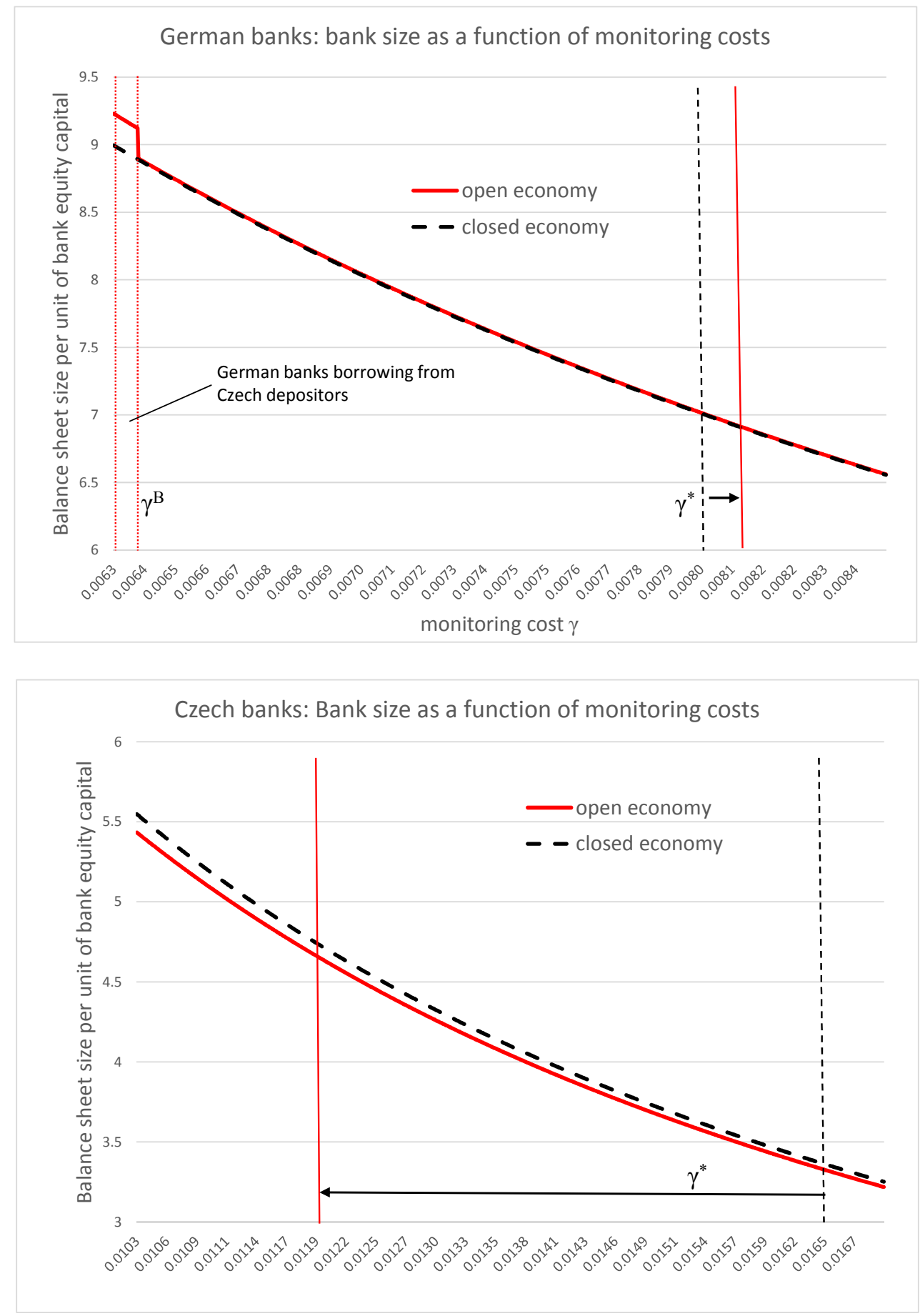

The figure illustrates how banking sector integration affects the size of banks. Specifically, the charts plot bank size as a function of monitoring costs in the closed economy (dashed line) and in the open economy (solid line). The top chart is for German banks, the bottom chart for Czech banks. The arrows in each chart indicate the shift of the respective bank entry cutoff $\gamma^{*}$, which moves up after banking sector integration in Germany and down in the Czech Republic. While all German banks grow as a result of banking sector integration, Czech banks shrink in size. 
Figure 3: Number of countries with at least $\mathrm{x}$ banks
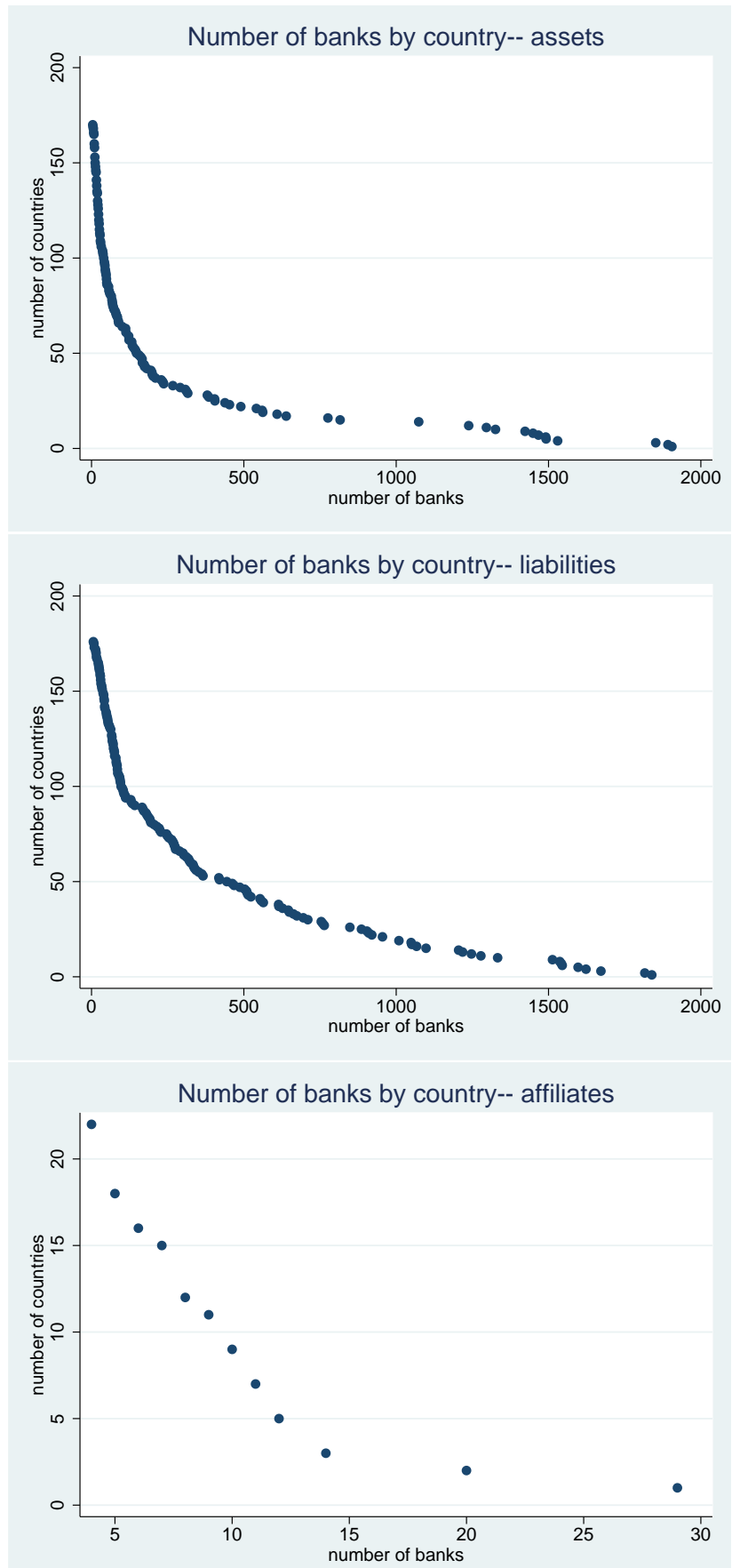

The figure illustrates that there are only a few countries in which many banks are active. Specifically, the chart plots the number of banks that are active in a given country against the number of countries in which at least that many banks are active. The top chart counts the number of banks that have foreign assets in a given market. The middle (bottom) chart is based on the number of banks with liabilities (affiliates) in a given country. For example, the top chart shows that there are around 20 countries in which at least 500 German banks hold assets. Source: Research Data and Service Centre of the Deutsche Bundesbank, External Position of Banks, 2005, own calculations. 
Figure 4: Number of banks active in at least $\mathrm{x}$ countries
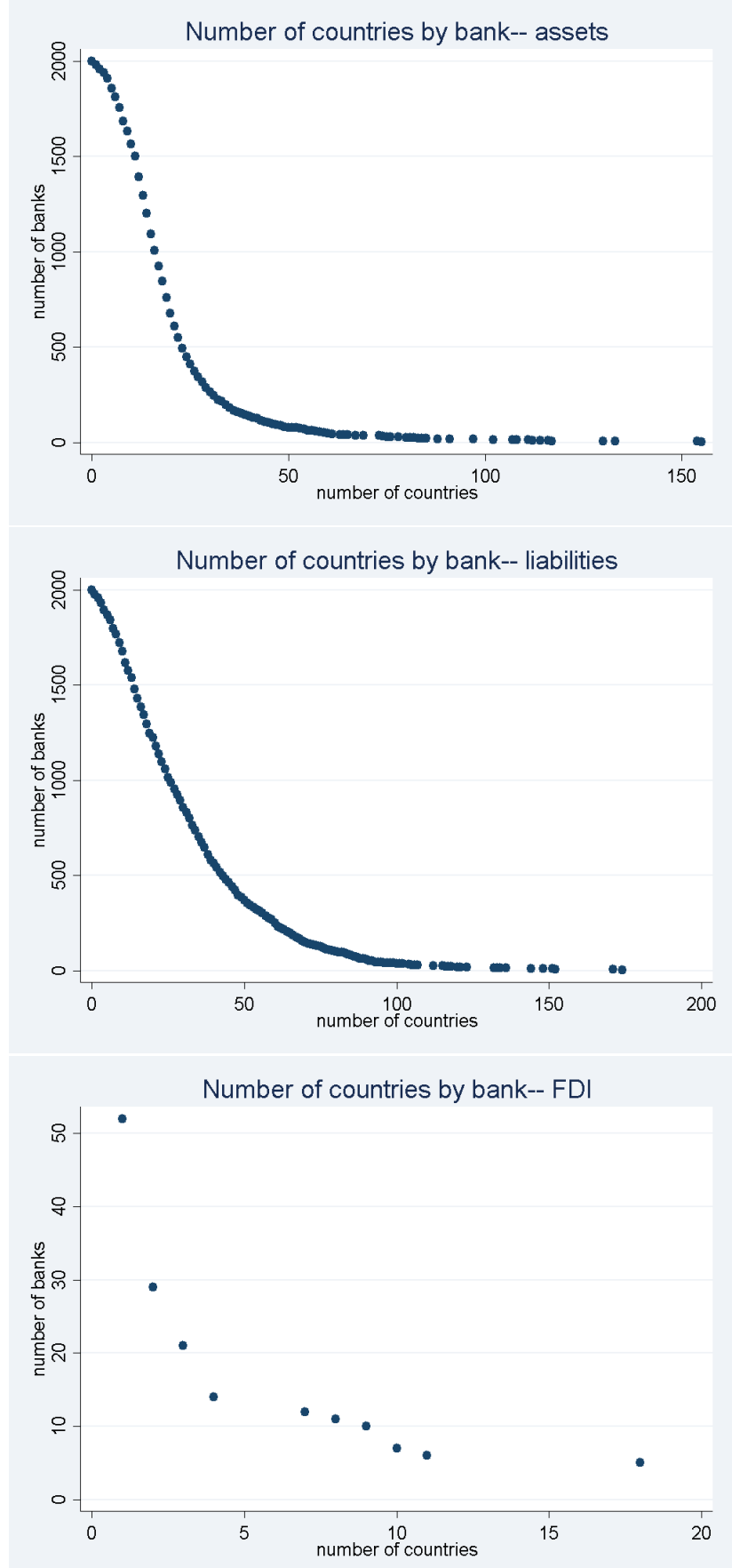

The figure illustrates that there are only a few banks which are active in many countries. Specifically, the chart plots the number of countries that a bank is active in against the number of banks active in at least as many countries. The top chart counts the number of countries in which a bank holds foreign assets. The middle (bottom) chart is based on the number of countries in which a bank has liabilities (affiliates). For example, the bottom chart shows that there are only 9 banks with affiliates in at least 10 countries. Source: Research Data and Service Centre of the Deutsche Bundesbank, External Position of Banks, 2005, own calculations. 
Figure 5: Average overhead costs of German banks active abroad as a function of country characteristics

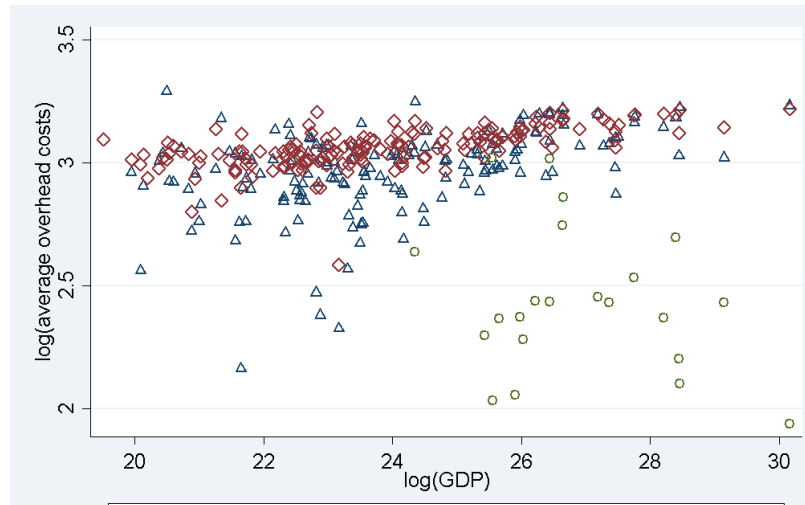

$\Delta$ banks with pos. foreign assets $\diamond$ banks with pos. foreign liabilities o banks with foreign affiliates

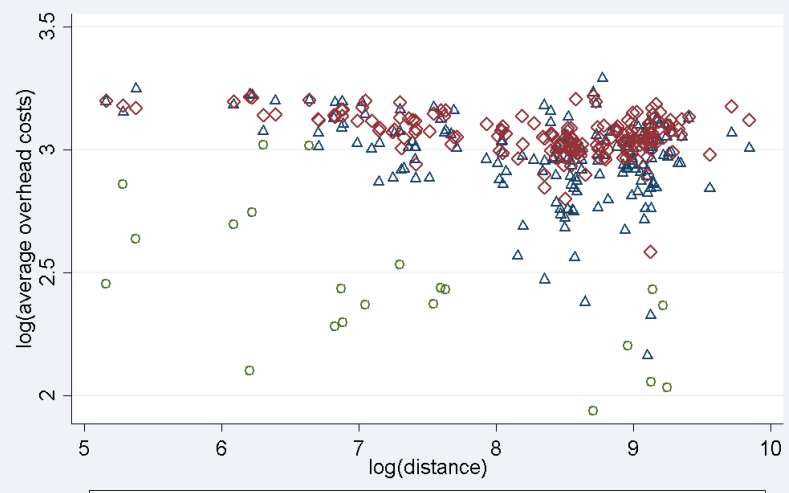

$\Delta$ banks with pos. foreign assets $\diamond$ banks with pos. foreign liabilities - banks with foreign affiliates

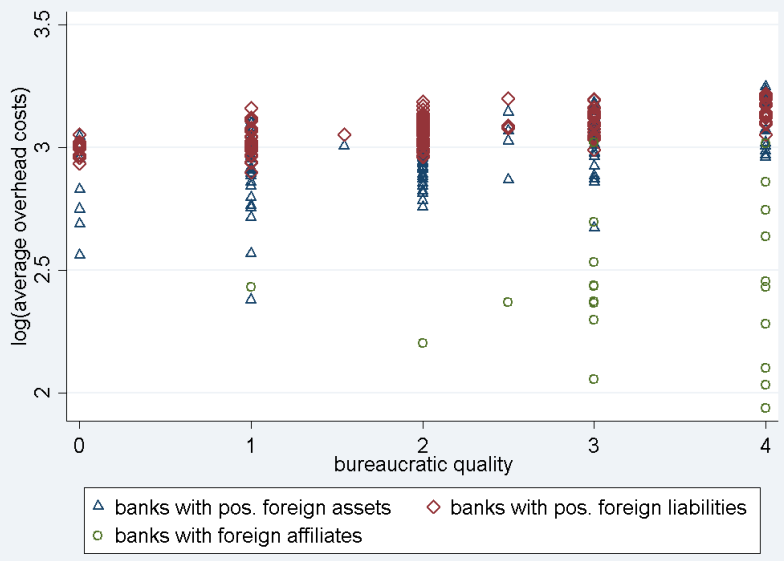

The figure illustrates the strong predictive power that individual host country characteristics have for the log average overhead costs of German banks that operate in a given host country. Specifically, in the top chart the average overhead costs of German banks with assets (triangle), liabilities (square) and affiliates (circle) in a country are plotted against the log GDP of the country. The middle (bottom) chart shows the same objects but plotted against log distance (bureaucratic quality). Source: External Position of Banks, Monthly Balance Sheet Statistics and Income and Loss data provided by Research Data and Service Centre of the Deutsche Bundesbank, Financial Freedom Index provided by Heritage Foundation, Bureaucratic Quality from Country Risk Guide provided by PRS Group, and GDP from the World Bank's World Development Indicators, 2005, own calculations. 